Prepared for the U.S. Department of Energy under Contract DE-AC05-76RL01830

\title{
Cultural Resources Review for Closure of the Nonradioactive Dangerous Waste Landfill and Solid Waste Landfill in the 600 Area, Hanford Site, Benton County, Washington - HCRC\# 2010-600-018R
}
JL Gutzeit
JJ Sharpe
EP Kennedy
BN Bjornstad
$\mathrm{R}$ DeMaris
M Venno
MS Sackschewsky
JR Christensen

February 2011

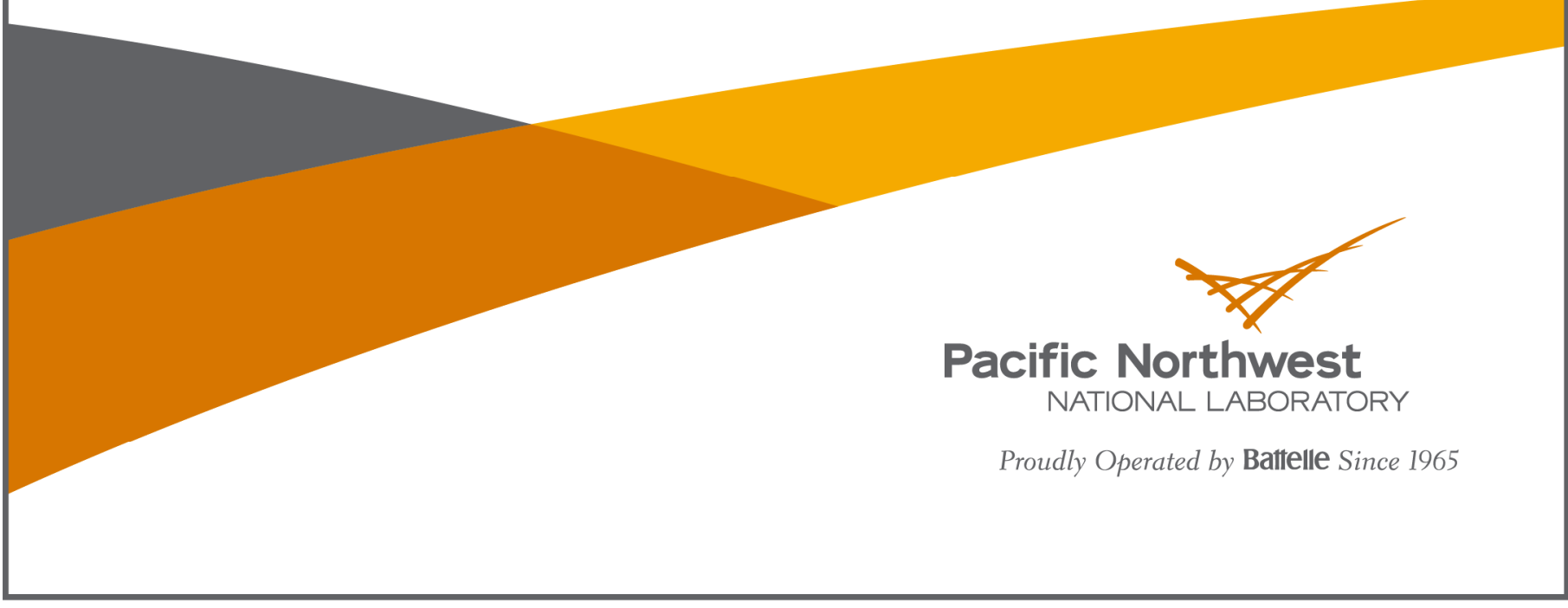




\title{
DISCLAIMER
}

This report was prepared as an account of work sponsored by an agency of the United States Government. Neither the United States Government nor any agency thereof, nor Battelle Memorial Institute, nor any of their employees, makes any warranty, express or implied, or assumes any legal liability or responsibility for the aceuracy, completeness, or usefulness of any information, apparatus, product, or process disclosed, or represents that its use would not infringe privately owned rights. Reference herein to any specific commercial product, process, or service by trade name, trademark, manufacturer, or otherwise does not necessarily constitute or imply its endorsement, recommendation, or favoring by the United States Government or any agency thereof, or Battelle Memorial Institute. 'The views and opinions of authors expressed herein do not necessarily state or reflect those of the United States Government or any agency thereof.

\author{
PACIFIC NORT'HWES T NATIONAL LABORAIORY \\ operated by \\ BATTELLE \\ for the \\ UNITED STATES DEPARTMENT OF ENERGY
}

under Contract DE-ACO5-76RLO1830 


\title{
Cultural Resources Review for Closure of the Nonradioactive Dangerous Waste Landfill and Solid Waste Landfill in the 600 Area, Hanford Site, Benton County, Washington - HCRC\# 2010-600-018R
}

\author{
JL Gutzeit \\ JJ Sharpe ${ }^{1}$ \\ EP Kennedy \\ MS Sackschewsky \\ BN Bjornstad \\ R DeMaris ${ }^{2}$ \\ M Venno ${ }^{1}$ \\ JR Christensen ${ }^{1}$
}

February 2011

Prepared for

the U.S. Department of Energy

under Contract DE-AC05-76RL01830

Pacific Northwest National Laboratory

Richland, Washington 99352

\footnotetext{
${ }^{1}$ CH2M HILL Area Office, Richland, Washington.

${ }^{2}$ CH2M HILL, Inc., Spokane, Washington.
} 


\section{CULTURAL RESOURCES REPORT COVER SHEET}

Authors: Jennifer L. Gutzeit, Ellen P. Kennedy, Mike Sackchschewsky, Bruce Bjornstad, Jim J. Sharpe, Raena DeMaris, Megan Venno, Jim Christensen

Title of Report: CULTURAL RESOURCES REVIEW FOR CLOSURE OF THE NONRADIOACTIVE DANGEROUS WASTE LANDFILL AND SOLID WASTE LANDFILL IN THE 600 AREA, HANFORD SITE, BENTON COUNTY, WASHINGTON - HCRC\# 2010-600-018R

Date of Report: January 2011

County: Benton

Section: 25 Township: 12 North, Range: 25 East; Sections 19-20, 27-31, 34-36 Township: 12 North, Range 26 East; Sections 19-20, 29-31 Township: 12 North, Range: 27 East

Quad: Iowa Flats, Gable Butte, Horn Rapids \& Hanford (7.5-minute series) Acres: 424

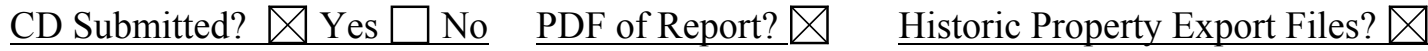

Does this replace a draft? $\square$ Yes $\bigotimes$ No

$\underline{\text { Archaeological Sites/Isolates Found or Amended? } \bigotimes \text { Yes } \square \text { No }}$

$\underline{\mathrm{TCP}(\mathrm{s}) \text { found? } \bigotimes \text { Yes } \square \text { No }}$

Does this report fulfill a DAHP permit requirement? $\square$ Yes \# $\quad$ \No

DAHP Archaeological Site \#: $\underline{\text { Laliik (TCP) }}$ $\underline{45 \mathrm{BN} 1029}$ 45BN01606 Army Loop Road
- Submission of paper copy is required.

- Please submit paper copies of reports unbound.

- Submission of PDFs is required.

- Please be sure that any PDF submitted to DAHP has its cover sheet, figures, graphics, appendices, attachments, correspondence, etc., compiled into one single PDF file.

- Please check that the PDF displays correctly when opened. 


\section{Summary}

The U.S. Department of Energy Richland Operations Office is proposing to close the Nonradioactive Dangerous Waste Landfill (NRDWL) and Solid Waste Landfill (SWL) located in the 600 Area of the Hanford Site. The closure of the NRDWL/SWL entails the construction of an evapotranspiration cover over the landfill. This cover would consist of a 3-foot (1-meter) engineered layer of fine-grained soil, modified with 15 percent by weight pea gravel to form an erosion-resistant topsoil that will sustain native vegetation. The area targeted for silt-loam borrow soil sits in Area $\mathrm{C}$, located in the northern central portion of the Fitzner/Eberhardt Arid Lands Ecology (ALE) Reserve Unit. The pea gravel used for the mixture will be obtained from both off-site commercial sources and an active gravel pit (Pit \#6) located just west of the 300 Area of the Hanford Site. Materials for the cover will be transported along Army Loop Road, which runs from Beloit Avenue (near the Rattlesnake Barricade) east-northeast to the NRDWL/SWL, ending at State Route 4. Upgrades to Army Loop Road are necessary to facilitate safe bidirectional hauling traffic. This report documents a cultural resources review of the proposed activity, conducted according to Section 106 of the National Historic Preservation Act of 1966.

The Area of Potential Effect (APE) includes four main areas of interest: 1) the NRDWL/SWL area, 2) the area targeted for silt-loam borrow soil (Area C), 3) Pit \#6, and 4) Army Loop Road. In accordance with Title 36 of the Code of Federal Regulations Part 800, ${ }^{1}$ the Washington State Historic Preservation Office, Confederated Tribes and Bands of the Yakama Nation, Nez Perce Tribe, Wanapum, Confederated Tribes of the Umatilla Indian Reservation, and the Confederated Tribes of the Colville Reservation were notified of the APE on March 8, 2010. A cultural resources field inventory of all unsurveyed portions of the project APE was completed between March 16 and March 24, 2010. The inventory included documenting Army Loop Road on a Historic Property Inventory form and updating two previously recorded anti-aircraft artillery sites (45BN1052 and HT-92-030) eligible for the National Register of Historic Places.

The National Register of Historic Places evaluation of Army Loop Road determined that Army Loop Road is not eligible for listing on the National Register of Historic Places. Therefore, project activities will result in no effect to historic properties. National Register-eligible archaeological sites 45BN1052 and 45BN01606 will not be adversely affected by project activities because they will be avoided. Area C is located within the National Register of Historic Places-eligible traditional cultural property of Laliik. Adverse effects are resolved and addressed in the "Amended Memorandum of Agreement (MOA) For Use of the Borrow Source at Area C, Hanford Site, Richland, Washington."

\footnotetext{
${ }^{1} 36$ CFR 800. "Protection of Historic Properties." Code of Federal Regulations, U.S. Government Printing Office, Washington, D.C.
} 


\section{Acronyms and Abbreviations}

$\begin{array}{ll}\text { AAA } & \text { anti-aircraft artillery } \\ \text { APE } & \text { Area of Potential Effect } \\ \text { CFR } & \text { Code of Federal Regulations } \\ \text { DOE-RL } & \text { U.S. Department of Energy Richland Operations Office } \\ \text { HCRC } & \text { Hanford Cultural Resources Case } \\ \text { MOA } & \text { Memorandum of Agreement } \\ \text { NEPA } & \text { National Environmental Policy Act of } 1969 \\ \text { NHPA } & \text { National Historic Preservation Act of 1966 } \\ \text { NRDWL } & \text { Nonradioactive Dangerous Waste Landfill } \\ \text { PNNL } & \text { Pacific Northwest National Laboratory } \\ \text { SHPO } & \text { State Historic Preservation Office } \\ \text { SWL } & \text { Solid Waste Landfill } \\ \text { TCP } & \text { Traditional Cultural Property } \\ \text { THPO } & \text { Tribal Historic Preservation Office } \\ \text { USACE } & \text { U.S. Army Corps of Engineers }\end{array}$




\section{Contents}

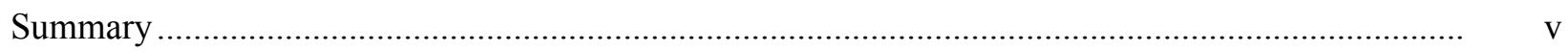

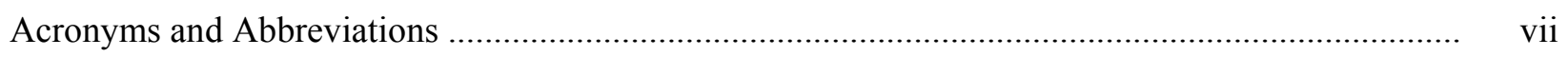

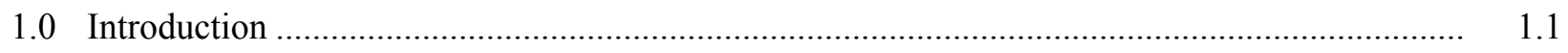

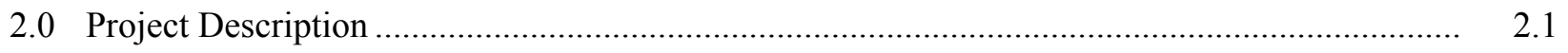

3.0 Notifications and Public Involvement ........................................................................

4.0 Environmental and Cultural Setting ........................................................................ 4.1

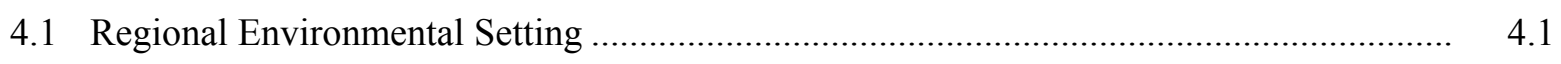

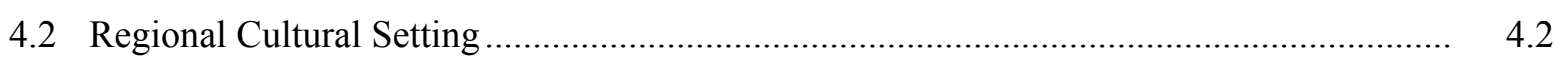

4.2.1 Native American Landscape ......................................................................... 4.2

4.2.2 Early Settlers/Farming Landscape..................................................................... 4.4

4.2.3 Manhattan Project and Cold War Cultural Landscape ........................................... 4.5

4.3 Environmental Setting of Project Area of Potential Effect ............................................. 4.6

4.4 Cultural Setting of Area of Potential Effect ................................................................. 4.7

5.0 Literature Review and Identification of Historic Properties................................................. 5.1

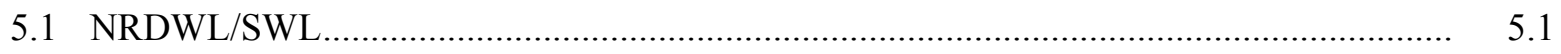

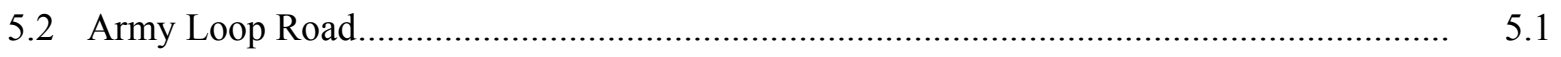

5.3 Area Targeted for Silt-Loam Borrow Soil (Area C) ................................................... 5.2

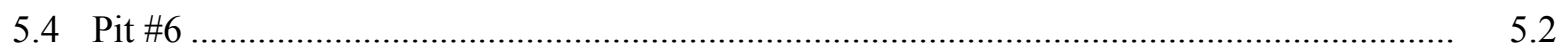

6.0 Cultural Resources Field Inventory Methods ................................................................. 6.1

7.0 Cultural Resources Field Inventory Results ...............................................................

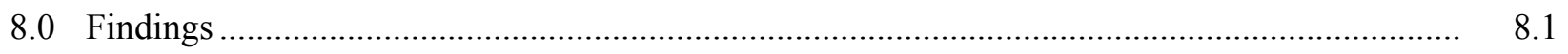

9.0 Administrative Process for Compliance with 36 CFR 800............................................... 9.1

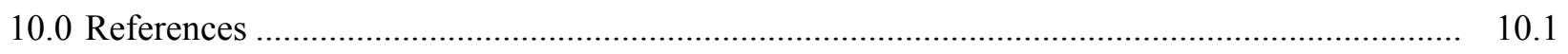

Appendix - Amended Memorandum of Agreement.................................................................... A.1 


\section{Figures}

2.1 General project areas in relation to the Hanford Site

2.2 Area of Potential Effect for the NRDWL/SWL, Army Loop Road, and area targeted for silt-loam borrow soil, overlaid on a U.S. Geological Survey topographic map, Washington State quadrangle, 7.5-minute series, Iowa Flats 1974, Gable Butte 1986, Horn Rapids 1986, and Hanford 1986.

2.3 Area of Potential Effect for the NRDWL/SWL, Army Loop Road, and area targeted for silt-loam borrow soil, overlaid on a 2006 aerial photograph

2.4 Area of Potential Effect for Pit \#6 overlaid on a U.S. Geological Survey topographic map, Washington State quadrangle, 7.5-minute series, Richland 1986

2.5 Area of Potential Effect for Pit \#6 overlaid on a 2006 aerial photograph.

7.1 Survey transects for the field inventory of Beloit Avenue and the western portion of Army Loop Road overlaid on a 2006 aerial photograph

7.2 Survey transects for the field inventory of the eastern portion of Army Loop Road to Route 4 South and the NRDWL/SWL area overlaid on a 2006 aerial photograph 


\subsection{Introduction}

Title 36 of the Code of Federal Regulations Part 800 (36 CFR 800) requires cultural resource reviews in accordance with Section 106 of the National Historic Preservation Act of 1966 (NHPA) whenever an undertaking is proposed by a federal agency. This document describes an NHPA Section 106 cultural resources review of a project proposed by the U.S. Department of Energy Richland Operations Office (DOE-RL) to close two landfills located on the Hanford Site.

For tracking purposes, the cultural resources review has been assigned Hanford Cultural Resources Case (HCRC) \# 2010-600-018. The review was completed by staff of the Pacific Northwest National Laboratory (PNNL) cultural resources program and cultural resources staff from CH2M HILL for DOE-RL and the CH2M HILL Plateau Remediation Company (CHPRC). This report also documents the results of the cultural resources inventory completed for a 424-acre (171-hectare) area affected by this undertaking (see Section 7).

Final copies of this report will be transmitted to DOE-RL for official distribution to area tribes and the Washington State Historic Preservation Office (SHPO) for their files, in accordance with 36 CFR 800. The DOE-RL Tribal Affairs and Cultural Resources Program maintains copies and associated records in its archive room at PNNL, located at the Sigma V Building, 3110 Port of Benton Boulevard, Richland, Washington.

The ensuing sections of this report reflect the steps of the review process. The proposed activities associated with the project are described in greater detail in Section 2. Notification of the Area of Potential Effect (APE) and invitation for public involvement in the review are described in Section 3, which also further describes each of the specific project areas within the APE. The environmental and cultural setting of the region and project APE are described in Section 4, followed by the results of the literature review and identification of historic properties in Section 5. The cultural resources field inventory field methods are provided in Section 6, followed by the results in Section 7. Section 8 presents the findings of the determinations of effect. Section 9 describes the administrative process for compliance with 36 CFR 800 . Section 10 contains the list of publicly available references cited in the text. An amended Memorandum of Agreement related to this project is provided in the Appendix. 


\subsection{Project Description}

The U.S. Department of Energy Richland Operations Office is proposing to close the NonRadioactive Dangerous Waste Landfill (NRDWL) and Solid Waste Landfill (SWL) located in the 600 Area of the Hanford Site. The proposed NRDWL/SWL closure project is located on the Hanford Site north of the city of Richland in Benton County, Washington. The project APE includes four main areas of interest: 1) the NRDWL/SWL area, 2) the area targeted for silt-loam borrow soil, 3) Pit \#6, and 4) Army Loop Road. All of these areas are located within the 600 Area of the Hanford Site (Figure 2.1).

Closure of NRDWL and SWL would consist of installing an evapotranspiration cover over the landfill areas and surrounding support area (see Figures 2.2 and 2.3). Material for the cover would be obtained from an offsite commercial source, an area targeted for silt loam material located within Borrow Area C (see Figures 2.2 and 2.3), and Pit \#6 (see Figures 2.4 and 2.5). The evapotranspiration cover would consist of a fine-grained, low-permeability soil modified with 15 percent by weight pea gravel to form an erosion-resistant topsoil that will sustain native vegetation. An effort would be made to maintain the natural dune and serpentine ridge crowns to blend the cover into the surrounding landscape. In addition, CHPRC plans to install several new and downgradient monitoring wells near the NRDWL/SWL facility and replace one existing well within the boundary of the NRDWL/SWL.

Army Loop Road would be used to transport material from Borrow Area C to NRDWL/SWL. Originally this road was constructed at a width of 20 feet (6 meters), but currently only about 18 feet (5.5 meters) are passable because of age deterioration and vegetation encroachment. Army Loop Road from Beloit Avenue to the northeastern corner of the landfill area would need to be upgraded and repaired to provide for safe, two-way traffic. Road repairs would consist of clearing existing road, expanding existing road, and laying gravel. Although the road would be used to transport material from Borrow Area $\mathrm{C}$ for cover installation, dust suppressants would be applied routinely, it would be graded, and additional gravel would be added as needed. Once the NRDWL/SWL cover is installed, road maintenance would return to routine maintenance. 


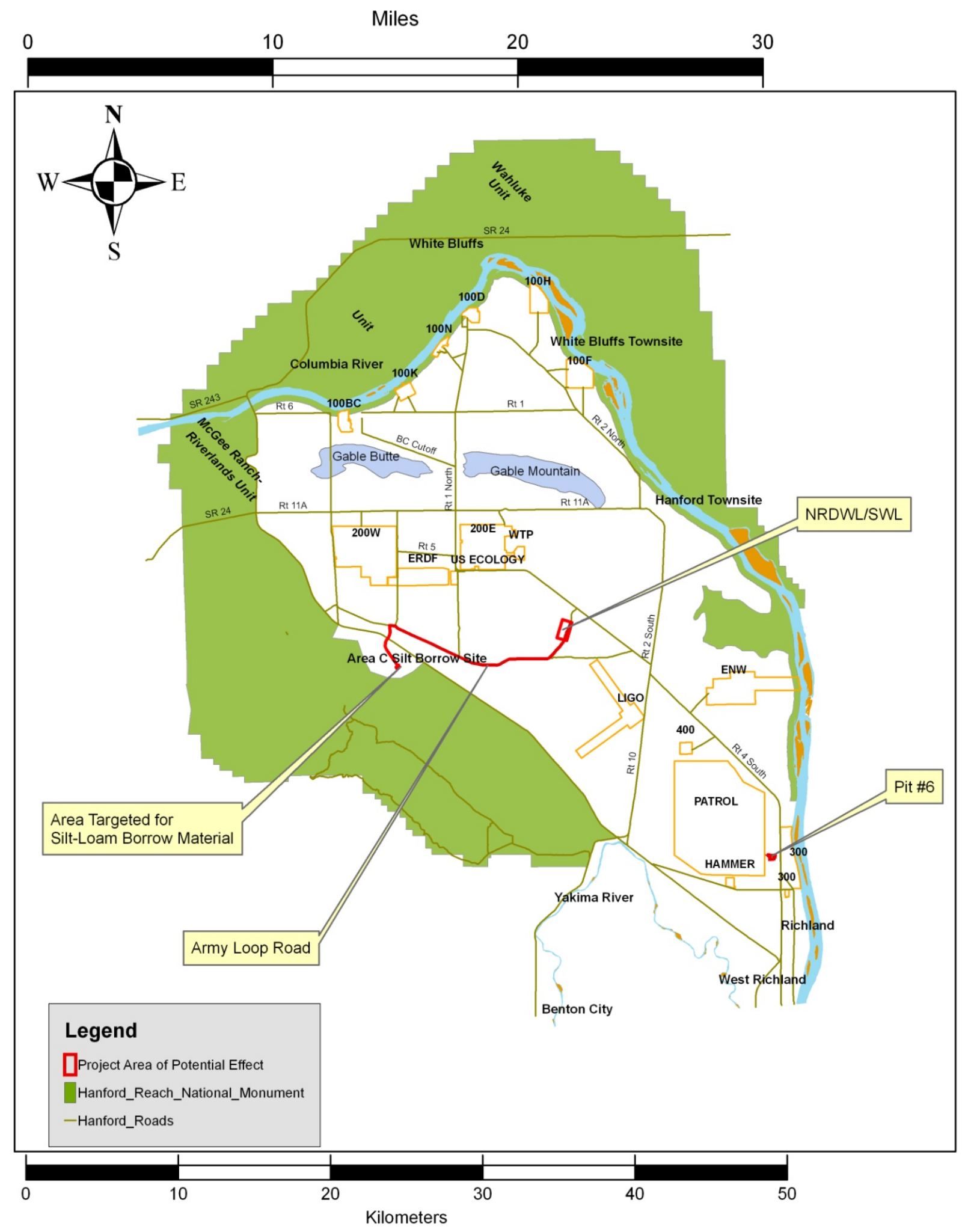

Figure 2.1. General project areas in relation to the Hanford Site. 


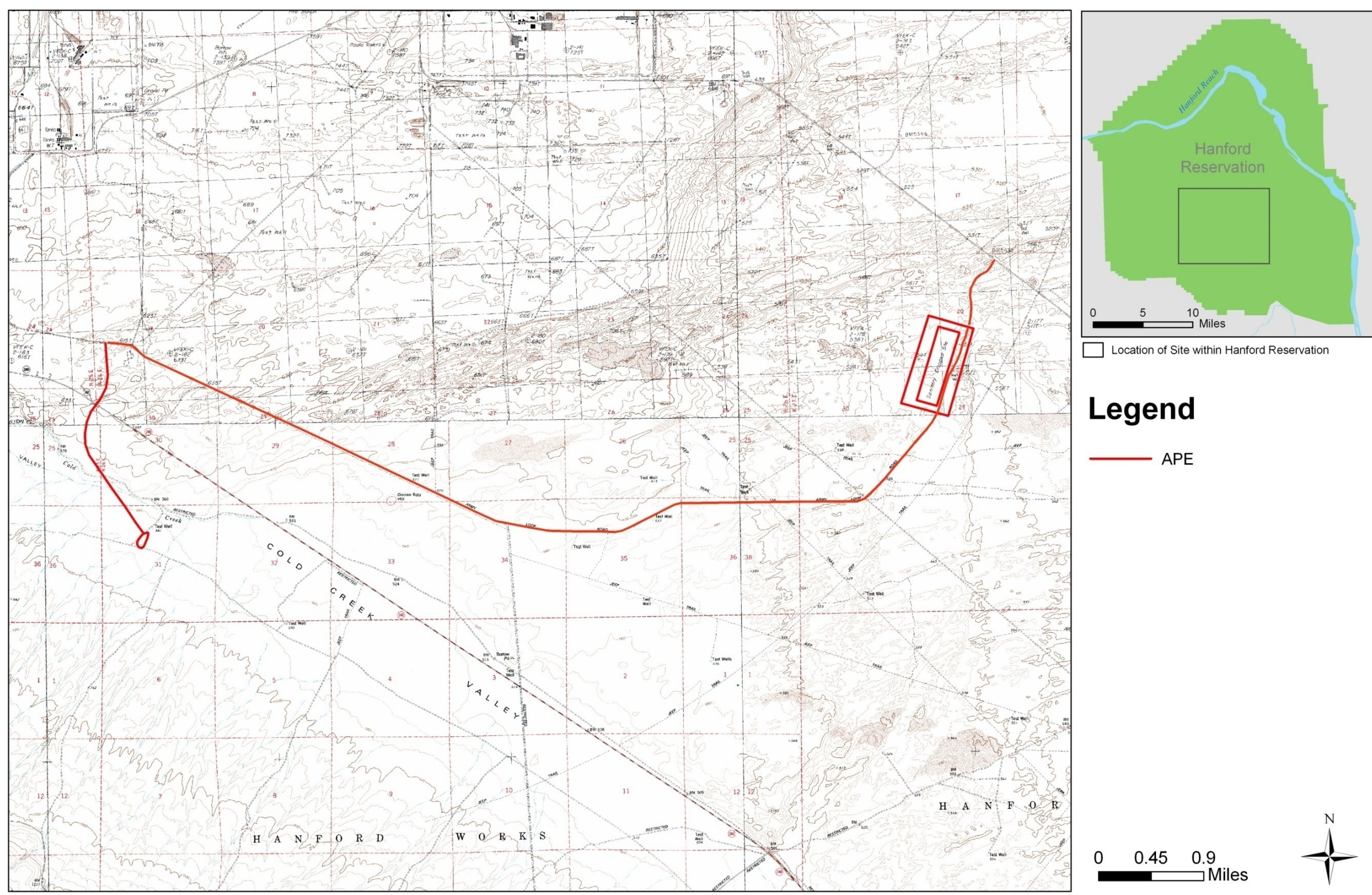

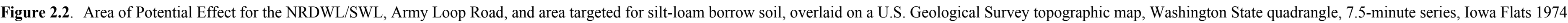
Gable Butte 1986, Horn Rapids 1986, and Hanford 1986. Township 12 N, Range 25 E, Section 25; Township 12 N, Range 26 E, Sections 19-20, 27-31, 34-36; Township 12 N, Range 27 E, Sections 19-20, 29-31. 

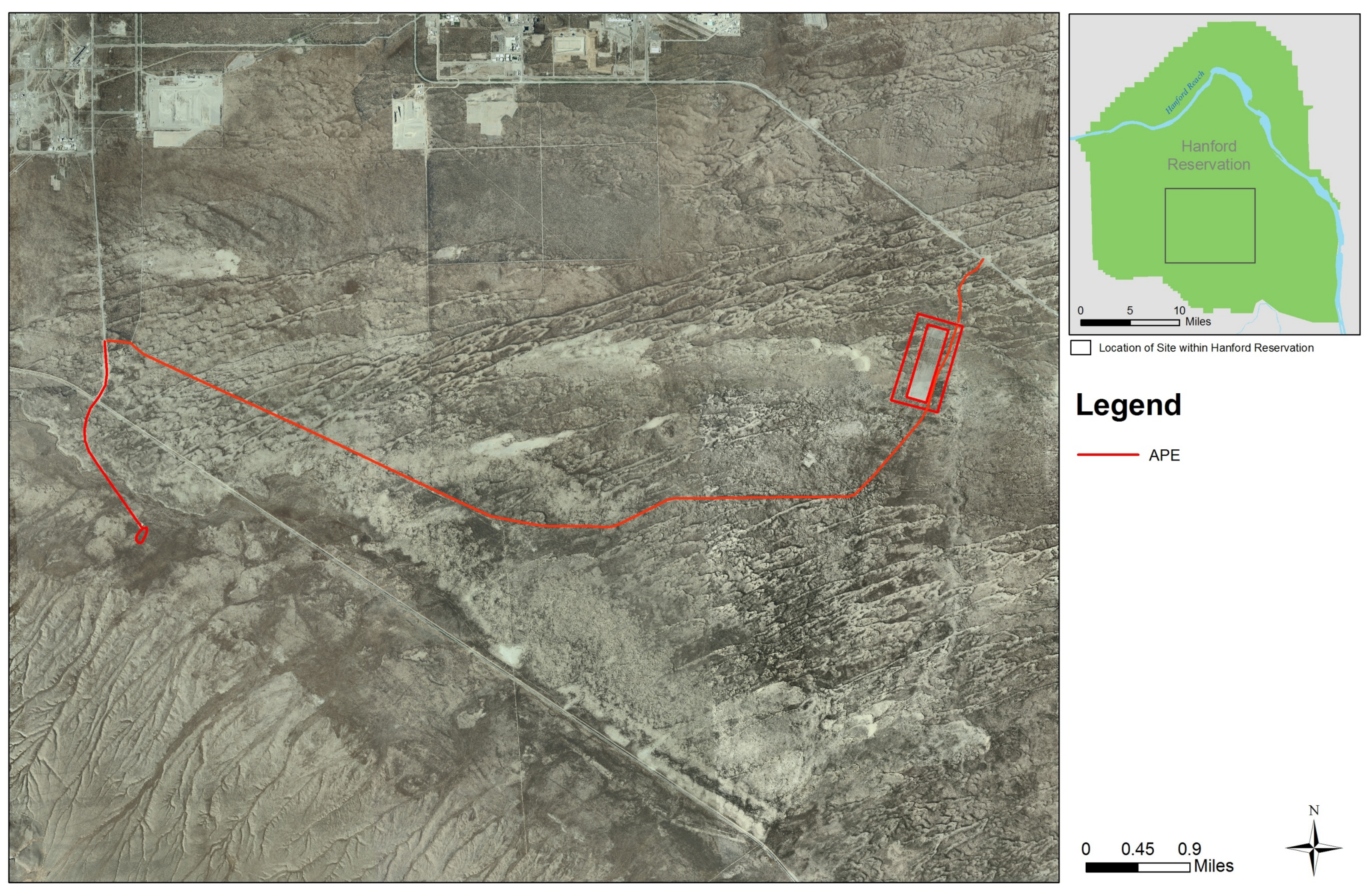

Legend

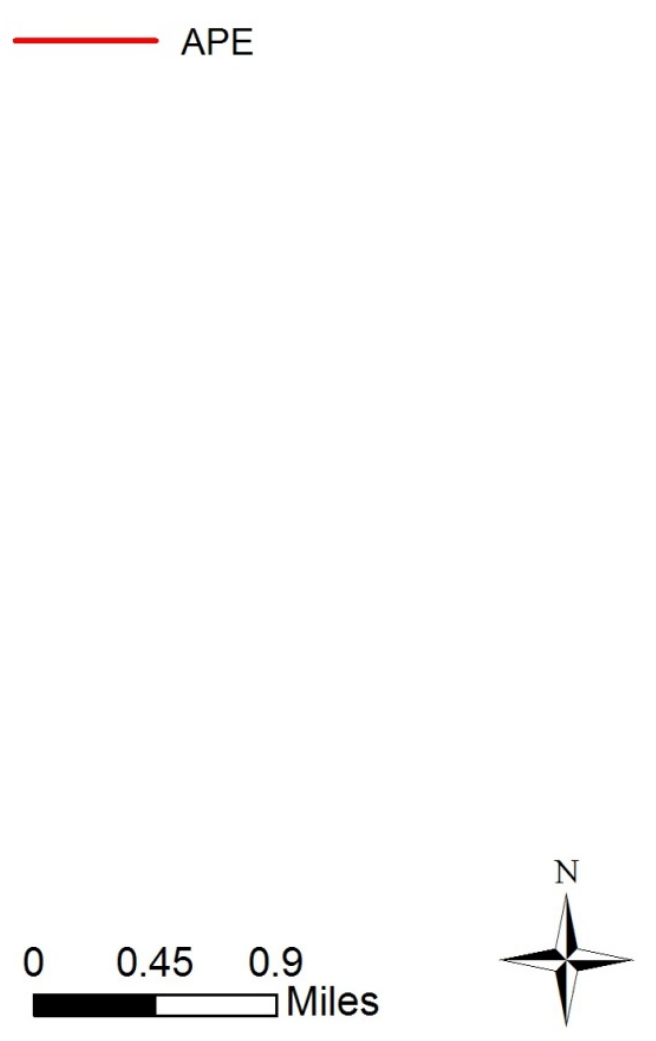

Figure 2.3. Area of Potential Effect for the NRDWL/SWL, Army Loop Road, and area targeted for silt-loam borrow soil, overlaid on a 2006 aerial photograph 


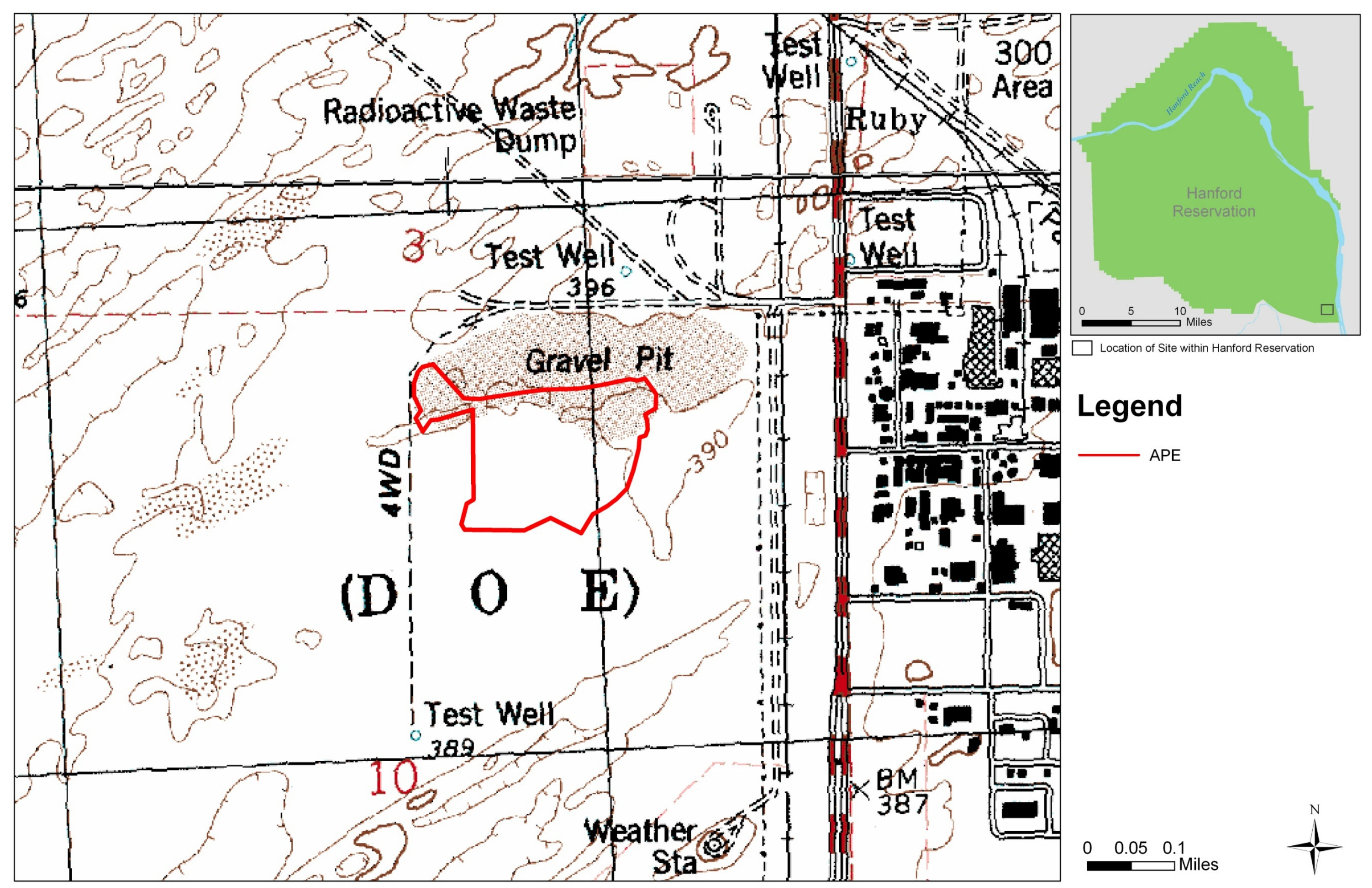

Figure 2.4. Area of Potential Effect for Pit \#6 overlaid on a U.S. Geological Survey topographic map, Washington State quadrangle, 7.5 -minute series, Richland 1986. Township 10 N, Range 28 E, Section 10. The red line indicates the boundary for Pit \#6. The 0.5 -acre expansion needed for the project lies well within this boundary area. 

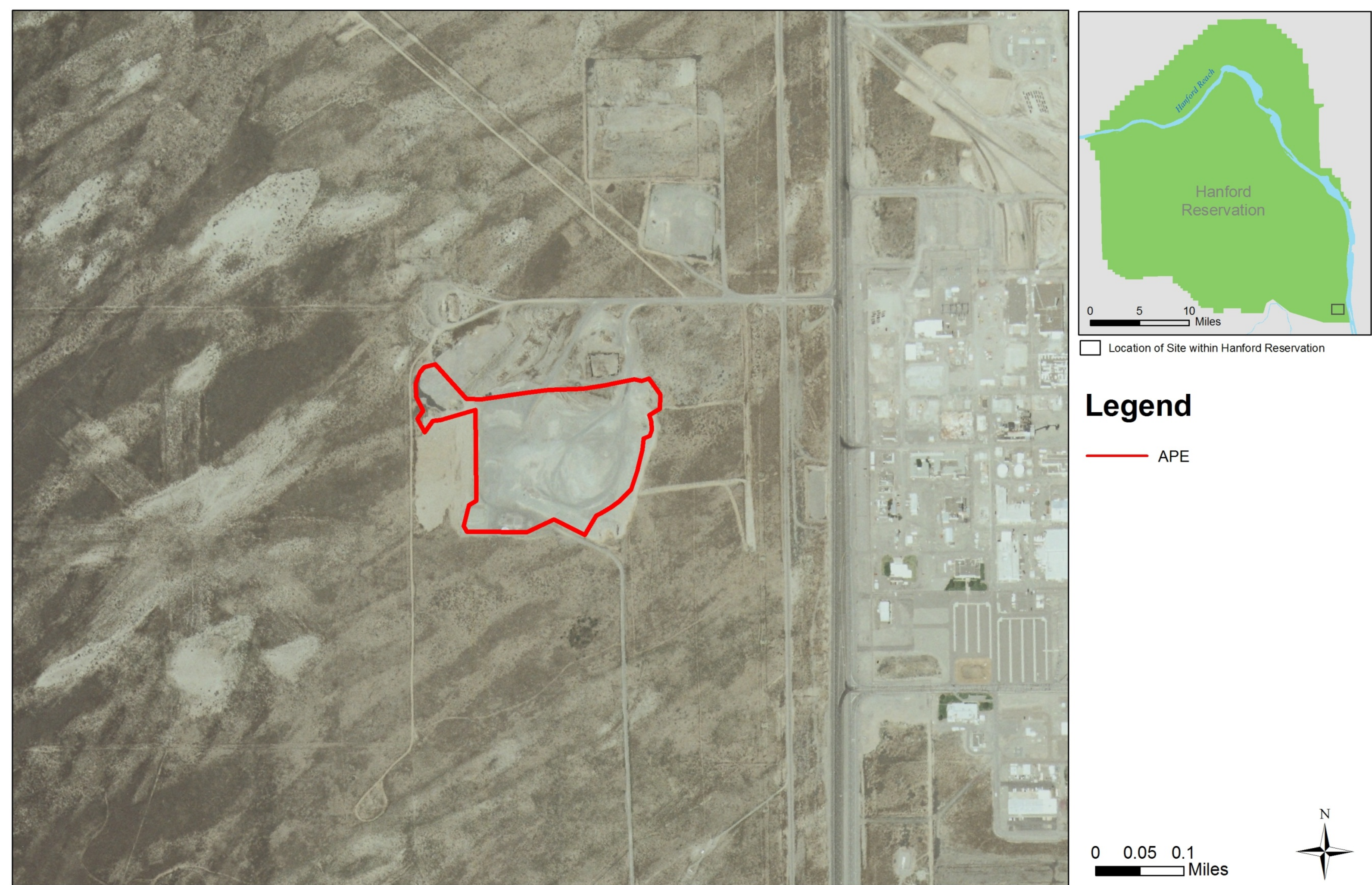

\section{Legend}

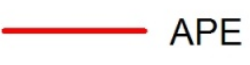

$\begin{array}{lll}0 & 0.05 & 0.1 \\ & & \end{array}$ Miles

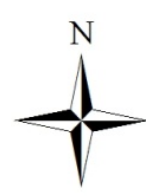

Figure 2.5. Area of Potential Effect for Pit \#6 overlaid on a 2006 aerial photograph. The red line indicates the boundary for Pit \#6. The 0.5 -acre expansion needed for the project lies well within this boundary area. 


\subsection{Notifications and Public Involvement}

In accordance with 36 CFR 800, on March 8, 2010, the Washington State Historic Preservation Office (SHPO), Confederated Tribes and Bands of the Yakama Nation, Nez Perce Tribe, Wanapum, Confederated Tribes of the Umatilla Indian Reservation, and the Confederated Tribes of the Colville Reservation were notified of the APE. SHPO concurred with the APE on March 10, 2010. No comments were received from the tribes.

An in-depth description of each of the four areas comprising the APE - the NRDWL/SWL area, area targeted for silt-loam borrow soil (located within Area C), Pit \#6, and Army Loop Road-was included in the notification. The four discrete areas were detailed as follows:

- NRDWL/SWL

The APE for the NRDWL/SWL area includes the main landfill area $(3,426,300$ square feet [318,314 square meters]) and the surrounding support area (staging/laydown area), which extends from the main landfill area to the north 367 feet (112 meters), south 314 feet (96 meters), west 551 feet (168 meters), and east 525 feet (160 meters). The main landfill areas and surrounding area would be approximately 5,549,770 square feet (515,590 square meters).

- Area targeted for silt-loam borrow soil

Borrow material for the cover would be obtained from a 45-acre (18-hectare) plot located within the Hanford Site Area C, which is situated just south of State Route 240 in the north-central portion of the Fitzner/Eberhardt Arid Lands Ecology (ALE) Reserve. The APE would be the 45-acre (18-hectare) plot located in the southeastern portion of Area C. Approximately 12,150,000 cubic feet of material $(3,703,320$ cubic meters) will be removed from this area through the use of standard excavation and earthmoving and earth-hauling equipment.

\section{- Army Loop Road}

The APE for Army Loop Road includes the portion to be expanded from Beloit Avenue to the northeastern corner of the main landfill support area (approximately 9 miles [14 kilometers]). The existing road will be cleared approximately 2 feet ( 0.6 meter) to its original 20 -foot (6-meter) width and will be expanded by 4 feet (1.2 meter), making the final road width approximately 24 feet ( 7 meters). At this stage of the project, it has not been determined which side of the road will need to be expanded; therefore, it is assumed that 8 feet (2.4 meters) on both sides of the existing road will be impacted.

- Pit \#6

The APE for Pit \#6 includes the total expansion area for the pit, which is estimated at roughly half of an acre (at 15 feet [5 meters] deep). 


\subsection{Environmental and Cultural Setting}

Much of the information provided in this section is derived from Hanford Site National Environmental Policy Act (NEPA) Characterization (Duncan et al. 2007) and the Hanford Cultural Resources Management Plan (DOE-RL 2003).

\subsection{Regional Environmental Setting}

The Hanford Site lies within the Columbia Basin ecoregion (Quigley et al. 1996) and consists of relatively undisturbed shrub-steppe habitats with narrow riparian corridors along the Columbia River and along several intermittent streams and waterways. The climate is typified by hot dry summers with cold wet winters, during which more than $50 \%$ of the precipitation occurs. Shrub-steppe on the Columbia Plateau is usually dominated by stands of big sagebrush (Artemisia tridentata) growing in association with various perennial cool-season bunchgrasses. Other common shrubs include gray and green rabbitbrush (Ericameria nauseosa and Chrysothamnus viscidiflorus) and spiny hopsage (Grayia spinosa), which grows intermixed with big sagebrush. Antelope bitterbrush (Purshia tridentata) is usually the dominant shrub on coarser, sandier soils on the site. Where the ground has been disturbed for agriculture or previous livestock grazing before the Hanford Site was set aside for nuclear production, the understory may be dominated by cheatgrass (Bromus tectorum). This winter annual grass is a successful invasive exotic competitor with native bunchgrasses and can increase after burning or other types of ground disturbance.

Wildfires are common in the semi-arid shrub-steppe, and the Hanford Site has been subjected to several large fires in the past three decades. These fires act to initially remove the sagebrush from the plant association but are generally not harmful to the perennial native bunchgrasses and forbs. Large acreages on the site (>50,000 acres [20,234 hectares]) were burned in 1981, 1984, 2000, and 2007. Recovery of big sagebrush and other shrub species has occurred in the areas burned in the 1984 fires, but little to no recovery of big sagebrush has occurred where the 1981, 2000, and 2007 fire footprints have overlapped.

The Hanford Site contains geologic characteristics similar to those found throughout the Columbia Basin (DOE 1988). Five major geologic events occurring over millions of years formed the soil, rocks, and geologic features (ridges and valleys) in the Columbia Basin. The area was flooded with numerous basaltic lava flows between 17 and 6 million years ago, forming the Columbia River Basalt Group. Concurrent with and following this basalt volcanism, tectonic forces folded the basalt, creating east-west anticlinal ridges and broad synclinal valleys characteristic of the Yakima Fold Belt subprovince of the Columbia Plateau (Myers and Price 1979, p. II-72). In this landscape, the ancestral Columbia River and its tributaries flowed across the area, leaving behind layers of sediment interbedded with some of the younger basalt flows. After the basalt volcanism ceased, the ancestral rivers continued to deposit sediments in the structural and topographic lows, forming the Ringold Formation (Newcomb et al. 1972). About 3.4 million years ago, western North America underwent regional uplift, resulting in a major drop in the hydraulic base level for the ancestral Columbia River system and an end to deposition of Ringold sediments. The base-level change resulted in regional erosion and downcutting of the ancestral rivers into the Ringold Formation, leaving higher elevations exposed to the arid climate that formed thick calcic paleosols. On the basin margins, sidestreams were actively eroding rocks and sediments from the emerging ridges and depositing gravel (mainly basalt clasts), sand, and silt into ancestral sidestreams, 
such as in Cold Creek and Dry Creek valleys. Ancestral river sediments and wind-blown loess were deposited in lower elevations of the basin. The paleosols and sediments superimposed disconformably on the erosional surface of the Ringold Formation are informally called the Cold Creek unit (DOE-RL 2002). With the onset of the last major Ice Age some 2.6 million years ago, the area was inundated by a series of cataclysmic Ice-Age floods (including the Missoula floods), which deposited a thick sequence of sediment in what is referred to informally as the Hanford formation (DOE-RL 2002; Bjornstad 2006). As many as 100 separate flood events have been postulated to have occurred during the last glacial cycle, 15,000 to 20,000 years ago (Waitt 1994). The largest of these floods had flow rates up to about 17 million cubic meters per second, ten times the combined flow rate of all the modern rivers of the world, making them arguably the largest recorded floods known to have occurred on Earth (O'Conner and Costa 2004). Temporary ponding of the Ice Age floodwaters behind Wallula Gap left behind ice-rafted erratic boulders and mounds of iceberg debris (berg mounds) as well as fossils of mammoths and other creatures caught up in the floods (Barton 1999; Last and Winsor 2007). During the last 15,000 years, fluvial and eolian processes further shaped the landscape and deposited locally derived sediments. Thin blankets of volcanic ash from Cascade volcanoes were also deposited.

\subsection{Regional Cultural Setting}

Cultural resources on the Hanford Site are diverse, ranging from early pre-contact times to the atomic age. The site contains an extensive record of human occupation documenting a series of overlapping cultural landscapes stretching back thousands of years, each layer of which tells the story of how people have utilized the landscape. Three distinct landscapes are defined: The Native American Cultural Landscape, the Early Settlers and Farming Landscape, and the Manhattan Project and Cold War Era Cultural Landscape.

\subsubsection{Native American Landscape}

For thousands of years American Indians have utilized the lands both within and around the Hanford Site (Spier 1936; Relander 1956; Walker 1998). When Euro-American explorers arrived in the early 1800 s, peoples currently referred to as the Wanapum were observed inhabiting numerous villages and fishing camps scattered throughout this segment of the mid-Columbia River. Neighboring groups known today as the Yakama, Umatilla, Cayuse, Walla Walla, Palus, Nez Perce, and Middle Columbia Salish frequented the area to trade, gather resources, and conduct other activities. Many descendants of these tribes and bands are affiliated with the Wanapum, Confederated Tribes and Bands of the Yakama Nation, Confederated Tribes of the Umatilla Reservation, Nez Perce Tribe of Idaho, or the Confederated Tribes of the Colville Reservation, and they retain traditional, cultural, and religious ties to Hanford's places and resources. The record of Native American use and history is reflected in the archaeological sites and traditional cultural places that are located across the Hanford Site.

More than 8,000 years of pre-contact human activity in the largely arid environment of the midColumbia River region have left extensive archaeological deposits along the river shores (Leonhardy and Rice 1970; Greengo 1982; DOE-RL 2003). Well-watered areas inland from the river also show evidence of concentrated human activity (Daugherty 1952; Leonhardy and Rice 1970; Greene 1975; Chatters 1982, 
DOE-RL 2003), and research ${ }^{1}$ has indicated ephemeral use of arid lowlands for hunting and other resource procurement activities. Throughout most of the region, hydroelectric development, agricultural activities, and domestic and industrial construction have destroyed or covered many of these deposits. Amateur artifact collectors have impacted numerous sites. Because the areas included in the Hanford Site were restricted to public access, archaeological deposits found in the Hanford Reach of the Columbia River and on adjacent plateaus and mountains are more protected than they are in many other areas.

Approximately 720 archaeological sites and isolated finds associated with the pre-contact period have been recorded on the Hanford Site; of these, 80 contain historic components as well. Pre-contact period sites common to the Hanford Site include pit house villages, various types of open campsites, spirit quest monuments (rock cairns), hunting camps, game drive complexes, and quarries in nearby mountains and rocky bluffs hunting/kill sites in lowland stabilized dunes; and small temporary camps near perennial sources of water located away from the river.

A historic context for the pre-contact period of the Hanford Site has been prepared as part of a National Register Multiple Property Documentation form to assist with the evaluation of the National Register eligibility of pre-contact archaeological resources (DOE-RL 1997).

The Hanford Reach and the greater Hanford Site, a geographic center for regional American Indian religious activities, is central to the practice of Indian religion of the region, and many believe the Creator made the first people here (DOI 1994). Indian religious leaders such as Smoholla, a prophet of Priest Rapids who brought the Washani religion to the Wanapum and others during the late 19th century, began their teachings here. Native plant and animal foods, some of which can be found on the Hanford Site, are used in the ceremonies performed by tribal members. Based on consultation with affected tribal members and interviews with tribal elders, it is known that prominent landforms such as Rattlesnake Mountain, Gable Mountain, and Gable Butte, as well as various sites along and including the Columbia River, remain sacred to them.

American Indian traditional cultural places within the Hanford Site include, but are not limited to, a wide variety of places and landscapes: archaeological sites, cemeteries, trails and pathways, campsites and villages, fisheries, hunting grounds, plant gathering areas, holy lands, landmarks, important places in Indian history and culture, places of persistence and resistance, and landscapes of the heart (Bard 1997). Because affected tribal members consider these places sacred, many traditional cultural sites remain unidentified. The DOE-RL Tribal Affairs and Cultural Resources Program continues to consult with Hanford tribes for input on these locations, as their importance is determined through methods that are mutually agreed upon by DOE and the American Indian community.

A historic context for the ethnographic/contact periods of the Hanford Site has been prepared as part of a National Register Multiple Property Documentation form to assist with the evaluation of the National Register eligibility of American Indian ethnographic resources (DOE-RL 1997).

\footnotetext{
${ }^{1}$ Woody D. A Proposed Model of Pre-Contact Land Use of the Hanford Site and Its Cultural Resources Management Applications. Unpublished master's thesis, Eastern Washington University, Cheney.
} 


\subsubsection{Early Settlers/Farming Landscape}

The Early Settlers/Farming landscape comprises those areas on the Hanford Site where people, mainly of European descent and some of other ethnicity, settled in the Columbia River Plateau prior to the start of the Manhattan Project during 1943. Non-Native American presence in the mid-Columbia began during 1805 with the arrival of the Lewis and Clark Expedition. It was not until the late 19th and early 20th centuries, however, that non-Native American peoples began intensive settlement on the Hanford Site. A record of their activities and use is present in the archaeological sites, traditional cultural places, and buildings and structures that are located throughout the Hanford Site.

A historic context for the Euro-American resettlement period (pre-Hanford era) has been prepared as part of a National Register Multiple Property Documentation form to assist with the evaluation of the National Register eligibility of historic archaeological resources, traditional cultural places, and historic structures (DOE-RL 1997).

The first Euro-Americans to pass near the Hanford Site were part of the Lewis and Clark expedition, which traveled along the Columbia and Snake rivers during their 1803 to 1806 exploration of the Louisiana Territory. The first European explorer to cross the Hanford Site was David Thompson, who traveled along the Columbia River from Canada during his 1811 exploration of the Columbia River. Other visitors included fur trappers, military units, and miners who traveled through the Hanford Site on their way to lands up and down the Columbia River and across the Columbia Basin. It was not until the 1860s that merchants set up stores, a freight depot, and the White Bluffs Ferry on the Hanford Reach. Chinese miners began to work the gravel bars for gold during the 1860s. Cattle ranches were established in the 1880s, and farmers followed during the next two decades. Agricultural development, irrigation districts, and roads were established in the eastern portion of the central Hanford Site. Several small towns, including Hanford, White Bluffs, Richland, and Ringold, grew up along the riverbanks during the early 20th century. The communities' accessibility to outside markets expanded with the arrival during 1913 of the Chicago, Milwaukee, \& St. Paul Railroad branch line (Priest Rapids-Hanford line) from Beverly, Washington. Ferries were established at Richland, Hanford, Wahluke, and Vernita. The towns and nearly all other structures were razed in the years after the U.S. Government acquired the land for the Hanford Engineer Works during 1943 (DOE-RL 2003).

Approximately 650 historic archaeological sites associated with the Early Settlers/Farming landscape, including an assortment of towns, farmsteads, corrals and domestic debris, have been recorded by the HCRP since 1987. Approximately 80 of these sites contain pre-contact components as well. Archaeological resources from the Early Settlers/Farming period are scattered over the entire Hanford Site and include numerous areas of gold mining features along the riverbanks of the Columbia and remains of homesteads, building foundations, agricultural equipment and fields, ranches, and irrigation features. Archaeological properties from this period include the Hanford Irrigation Canal; Hanford Townsite; Wahluke Ferry; White Bluffs town site; Vernita Ferry; White Bluffs Road; and Chicago, Milwaukee, \& St. Paul Railroad Priest Rapids-Hanford branch line and associated stops.

Traditional cultural places associated with the Early Settlers/Farming landscape that are located on the Hanford Site include structures and places that are important to descendants of pre-1943 settlers in the region. These places are deeply rooted in the memories of local residents and include, but are not limited 
to, numerous home sites and town sites, orchards, fields, and places of former community activities, e.g., swimming holes and town square. Previous residents of the region and their descendents visit their homes annually with friends and family.

Although most of the Early Settlers/Farming structures were demolished by the U.S. Government to build infrastructure for the Hanford Engineer Works during 1943 (DOE-RL 2003), a small number of buildings associated with the Early Settlers/Farming landscape remain standing today. They include the Hanford Irrigation and Power Company pumping plant at Coyote Rapids, the high school and electrical substation at the Hanford town site, First Bank of White Bluffs, Bruggemann's fruit warehouse, and the blacksmith cabin at the East White Bluffs ferry landing. These structures are located near the Columbia River.

\subsubsection{Manhattan Project and Cold War Cultural Landscape}

The Manhattan Project and Cold War era landscape is composed of cultural resources associated with plutonium production, military operations, research and development, waste management, and environmental monitoring activities that took place beginning with the establishment of the Hanford Site (Hanford Engineer Works) during 1943 to the end of the Cold War during 1990.

The Hanford Site built environment is an industrial landscape that consists of buildings and structures constructed during the Manhattan Project and Cold War period. This industrial landscape makes up the Hanford Site Manhattan Project and Cold War Era Historic District. The DOE Richland Operations Office, the State Historic Preservation Officer, and the Federal Advisory Council on Historic Preservation, through a programmatic agreement to manage the Manhattan Project and Cold War built environment, determined that a historic district afforded the best means to inventory, assess, and mitigate the most significant buildings and structures constructed during the Manhattan Project and Cold War. Industrial, scientific, administrative, environmental monitoring, waste management, infrastructure, and military facilities constructed during the Manhattan Project and Cold War era can be found in all of the Hanford Site areas.

Although buildings and structures representing this era are located throughout the site, evidence of military operations consists mostly of archaeological remains. Military operations in various forms took place on the site from World War II to the early 1960s. Most of the military operations, however, took place beginning with the establishment of Camp Hanford by the U.S. Army during 1950-1951 until its closure in 1961. Camp Hanford was a military outpost, with the main cantonment located in North Richland and forward positions situated throughout the Hanford Site consisting of anti-aircraft artillery sites and Nike missile installations.

Historic contexts were completed for the Manhattan Project and Cold War eras as part of a National Register Multiple Property Documentation Form prepared for the Hanford Site to assist with the evaluation of National Register eligibility of buildings and structures site wide (DOE-RL 1997).

Additionally, historical narratives and individual building documentations have been completed for the History of the Plutonium Production Facilities at the Hanford Site Historic District, 1943-1990 (DOE-RL 2002b). Five hundred twenty-eight Manhattan Project and Cold War era buildings/structures and complexes are eligible for the National Register as contributing properties within the Historic District. Of that number, 190 are recommended for individual documentation. DOE-RL has also 
completed assessments of the contents of the contributing buildings and structures locating and identifying Manhattan Project and Cold War era artifacts that may have interpretive or educational value for museum exhibit purposes (DOE-RL 1998).

Archaeological remains of military sites associated with the Manhattan Project and Cold War landscape are scattered throughout the Hanford Site 600 Area. These archaeological resources are located mainly within the former Camp Hanford forward positions, the 16 anti-aircraft artillery sites that encircled the 100 and 200 Areas, and the three Nike missile installations on Wahluke Slope. (A fourth Nike position, in relatively intact condition, is located at the base of Rattlesnake Mountain on the Arid Lands Ecology Reserve Unit.) The Nike position on the ALE Reserve is eligible for inclusion in the National Register as a contributing property within the Hanford Site Manhattan Project and Cold War Era Historic District. Five of the 16 anti-aircraft artillery sites are eligible for the National Register.

The anti-aircraft artillery (AAA) and Nike missile sites were strategic components in Camp Hanford's military defense of the site's plutonium production facilities during the 1950s. Potential archeological resources at these sites include former gun emplacements, launch and radar sites, concrete foundations and pads, pathways/sidewalks, associated dumpsites, small arms firing ranges, and ammunition caches.

The archaeological remains of the Atmospheric Dispersion Test Facility Grid are located in the Hanford Site east of the 200 West Area. The facility was used for monitoring airborne waste dispersions during the operation of the plutonium production facilities on the Hanford Site.

Historic built resources documented from the Manhattan Project and Cold War era include buildings and structures found in the 100, 200, 300, 400, 600, 700, and 1100 Areas. The most significant of these are the plutonium production and test reactors, chemical separation and plutonium finishing buildings, and fuel fabrication/manufacturing facilities. The first reactors, 105-B, 105-D, and 105-F, were constructed during the Manhattan Project. Plutonium for the first atomic explosion and the bomb dropped on Nagasaki, Japan, at the end of World War II were produced at the Hanford Site. Additional reactors and processing facilities were constructed after World War II during the Cold War period. All reactor containment buildings still stand, although many ancillary structures have been removed, and $\mathrm{C}$, $\mathrm{D}, \mathrm{DR}, \mathrm{F}$, and $\mathrm{H}$ reactors have been considerably modified by interim safe storage (i.e., cocooning) activities.

\subsection{Environmental Setting of Project Area of Potential Effect}

All components of the project APE are located within the 600 Area of the Hanford Site. The dominant plant species observed within the project area include cheatgrass (Bromus tectorum), a nonnative annual weed with interspersed varieties of bunch grasses. Dominant forms of flowering plant species observed within the project APE include Russian thistle (Solsola kali), Jagged chickweed (Holosteum umbellatum), and tumble mustard (Sisymbrium altissimum). Big sagebrush (Artemisia tridentata) was found to be the prevalent overstory vegetation along Army Loop Road (Sackschewsky 2010). Surface geology across the APE is characterized by flood deposits that occur in sand dunes that trend in a southwest to northeast direction, along the predominant wind direction. Gravel Pit \#6 consists of exposed gravels that were deposited during the Ice Age (Pleistocene) floods from glacial Lake Missoula. Above the flood gravels, the edge of the pit is characterized by sand dunes consisting of windblown deposits that have been reshaped by wind over the past 13,000 years. The stretch of land 
between Area $\mathrm{C}$ and the NRDWL/SWL is characterized by slow-moving water deposits (slackwater deposits) from the Pleistocene floods (discussed in Section 4.1). Above these slackwater flood deposits lay interspersed dunes created from more recent wind activity, similar to those seen at the edges of Pit \#6. Potential for buried cultural materials would not exist within the slackwater deposits (Bruce N. Bjornstad, PNNL, personal communication, 2010). It should also be noted that previous geological investigations of Area $\mathrm{C}$ have identified areas based on their potential to contain subsurface cultural deposits. The area targeted for borrow silt-loam material for the current project falls within the Cold Creek flood plain zone within Area C. According to the cultural model developed for this area, no temporary or permanent settlement would have taken place here in prehistoric times. Additionally, areas located within the Area C slackwater flood deposit zone (just south of the project APE) have been determined to contain no potential for subsurface deposits.

\subsection{Cultural Setting of Area of Potential Effect}

A large portion of the project area is located just south of the 200 East and 200 West Areas, two of the original Hanford Site areas established for the Manhattan Project in 1943, primarily for plutonium separation and finishing facilities (Marceau et al. 2003). Army Loop Road, also called Valley Road, was constructed by the U.S. Army Corps of Engineers shortly after Hanford lands were allocated for use for Manhattan Project operations. The road was constructed just south of the 200 Areas and connected Route 4 South on its east side with Route 11-A, or Hanford-Cold Creek Road, on its west side. Army Loop Road played a role in the matrix of AAA sites in place from 1950 to 1958. AAA sites were established as air defense systems to protect the reactors and chemical separation plants associated with Manhattan Project operations. Sixteen AAA sites were strategically placed in areas along the North Slope, the Riverlands Unit, the 100 Areas, and the 200 Areas. Four of these AAA sites were located along Army Loop Road, just south of the 200 Areas. The road connected these AAA sites with one another and provided an easy avenue for communication and transport. Cultural resources surveys of the portions of the project area and within the vicinity of the project area have located mostly historic era and pre-contact era isolated finds. Ethno-historic documentation indicates that during prehistoric and ethnohistoric times, people occasionally hunted in the area; travel occurred along the trail that later became known as the White Bluffs Road, which runs from White Bluffs to Rattlesnake Springs and beyond.

A review of 1880 General Land Office (GLO) maps confirms use of the area predominantly for travel and migration and likely sheep herding and grazing. Most of the project APE was owned by the Northern Pacific Railway under a land patent granted in November 1895. The land was acquired under an 1864 railroad grant for the construction of a railway from Lake Superior to Puget Sound. The remainder of the land covered by the APE was owned by the State of Washington or was free land, with no owners listed. The 1916 Coyote Rapids topographic map depicts the Cold Creek Road just north of the area targeted for silt-loam borrow material. Cold Creek Road is depicted as a dirt road, running approximately west-east, just north of Cold Creek. The 1916 map did not indicate any evidence of permanent historic settlement in the project area, with the exception of the Benson Ranch located approximately 2.5 miles northwest of the area targeted for silt-loam borrow soil. Maps from the 1943 Metsker's Atlas of Benton County indicate that land ownership in the project area was associated predominantly with public entities such as the Northern Pacific Railway, J. M. Coleman Company, the State of Washington, and the United States of America. Private ownership in the area includes Jesse O. Thomas Junior and Ina C. Wenner. Aerial photographs from 1943 depict the project area as largely undeveloped and, given the land ownership in the area, likely used for animal grazing as well as travel. 
Pit \#6 is located just west of the 300 Area of the Hanford Site. Much of the 300 Area has seen extensive disturbance in conjunction with industrial growth associated with the Manhattan Project and Cold War operations. Prior to 1943, the 300 Area was known to have been utilized by American Indian tribes for camp sites during pre-contact times, particularly in areas adjacent to the Columbia River. The area was also an important location for Euro-American settlers, providing the basis for a developed farming community known as Fruitvale. The 300 Area was also a major part of the Richland Irrigation District; the Richland ditch ran approximately parallel to the 300 Area on the west side of State Route 4. A number of historic sites and isolated finds have also been recorded within the vicinity of the 300 Area, with most of these dating to these earlier agricultural times.

A review of the 1880 GLO maps reveal that the area associated with Pit \#6 was owned, almost exclusively, by private owners. Northern Pacific Railway still held land claims from the 1864 railroad grant discussed above, but the area was predominantly privately owned. Private ownership in the area included John D. McCarthy, Olaf T. Melde, Elam D. Young, and Harriet E. Pass. Each of these was a sale-cash entry, and all were granted in the early 1900s (1911-1918). These early settlers were likely the beginning of what was to become Fruitvale. The 1916 Pasco topographic map shows that the area within the vicinity of Pit \#6 saw a boom in development with the installation of numerous roadways and structures not seen on the previous 1880 GLO maps. The name Fruitvale appears on the map, and a number of irrigation ditches/drainages also are depicted, including the Richland ditch, located just west of Pit \#6. A number of primary and secondary roadways were constructed along what is now the 300 Area, connecting Fruitvale with Richland to the south. Maps from the 1943 Metsker's Atlas of Benton County indicate that the area that had previously been privately owned now belonged to public entities, including the United States, Benton County, and the Richland Irrigation District. Fruitvale still appears on the map, along with an increase in the number of primary roadways throughout the area. A comparison of the 1916 U.S. Geological Survey topographical map and the 1943 Metsker maps indicates that the area underwent extensive development during that time interval, especially downriver toward the city of Richland. On the 1943 map, the Richland ditch is depicted running roughly north-south on the west side of Pit \#6, with other minor irrigation ditches/canals branching off it. The increase in the amount of public land associated with the irrigation canals highlights the likely importance of these canals to the agricultural setting within this area during this period of time. 


\subsection{Literature Review and Identification of Historic Properties}

A records and literature search was conducted to identify previous cultural resources investigations and cultural resources located within the project APE and within the vicinity of the project APE. This information provides additional context for the types and significance of cultural resources that may be located within the project APE.

The search revealed that much of the project area with the exception of the Army Loop Road area has been inventoried for cultural resources. Additionally, several surveys have been completed within the vicinity of the project APE, locating a few cultural resources, most associated with historic use at the Hanford Site. Aerial photographs from 2006 also were consulted to establish extent of disturbance in each of the project areas as a basis for considering the need to perform additional cultural resource inventory of these areas.

\subsection{NRDWL/SWL}

Aerial photographs of the area reveal that the fenced portion of the NRDWL/SWL has witnessed extensive ground disturbance. Conversely, the proposed support area surrounding the landfills remains moderately undisturbed, with natural topography and vegetation relatively intact. Most of the landfill and proposed support area have been surveyed for various projects dating from 1987 through 1999. No cultural resources have been recorded by these surveys within the project APE. One survey completed in 1999 successfully located one historic isolate (H3-427) within the vicinity of the current APE, consisting of a hole-in-cap metal milk can dating to the late 1800s or early 1900s. In addition to the historic isolate, the project recorded Arc 5 Road and some associated air monitoring stations. These associated features date to the post-1943 era and are part of the Atmospheric Dispersion Test Facility Grid system located on the Hanford Site. These features were determined eligible for listing on the National Register as contributing to the Manhattan Project/Cold War Era Historic District.

\subsection{Army Loop Road}

Aerial photographs show that the north and south sides of Army Loop Road, from Beloit Avenue to the northeastern corner of the NRDWL/SWL support area, are undisturbed, with natural topography and vegetation intact. Minor disturbances are apparent from the existence of intersecting dirt roadways along the stretch of road included within the APE. Records indicate that portions of the Army Loop Road project area have been previously investigated by four survey efforts dating between the late 1980s and 2006. No cultural resources have been identified in the project APE by these surveys.

Additionally, nine other cultural resource investigations have been performed adjacent to various segments of Army Loop Road. These date from the late 1980s and continue into 2007. Two National Register-eligible AAA sites (45BN01606 and 45BN1029) are located within the vicinity of the project APE. Site 45BN1029 (Position H-42) was the location of Battery A of the 518th AAA Battalion. The site contains the remains of four artillery revetments, constructed from dimensional lumber and sandbags. The site also contains a small bottle dump, with items dating from the early to mid-1950s. Site 45BN01606 (Position H-50) was the site of Battery C of the 518th AAA Battalion. The site contains a 
number of features, including four artillery revetments, the remains of a former maintenance shop, various concrete building slabs and walkways, building foundations, surface debris scatters (containing barbed wire, fence posts, carbide batteries, and other artifacts) and a concrete monument dedicated to the 518th Gun Battalion. In 1995, when the sites were evaluated, a mitigation plan was also developed for a project to address safety concerns at these sites. Because avoidance of these AAA sites was not possible due to the safety concerns present, recommendations for documentation were outlined in an effort to reduce the adverse effects of the cleanup activities. In the case of Site 45BN1029, most cleanup activities were allowed to proceed, including the filling and cleanup of four manholes associated with the site septic system. The project had also proposed to remove the four gun revetments, but it was determined that further documentation of these features was needed prior to removal. These revetments were never removed. In the case of 45BN01606, most of the proposed hazard mitigation activities did not adversely impact the site and required no mitigation. However, cultural resources staff recommended further investigation and recordation of the four gun revetments and an additional sandbag feature at the site prior to removal. Additionally, three isolated finds; a tertiary cryptocrystalline flake, a retouched secondary cryptocrystalline flake, and an early twentieth-century hole-in-cap can were identified within the vicinity of the project APE.

\subsection{Area Targeted for Silt-Loam Borrow Soil (Area C)}

Aerial photographs show that the proposed site for excavation of borrow material is located in a relatively undisturbed area. The proposed excavation, staging/lay down areas, and entry route for borrow material have been surveyed within the last 5 to 7 years by three separate survey efforts. No cultural resources have been recorded by these surveys within the project APE. Borrow Area C is also located within Laliik, a National Register-eligible traditional cultural property. A 2006 survey recorded an isolated battered cobble tool) located within the vicinity of the project APE, and the historic Cold Creek Valley-Richland Road, which runs just north of the current project APE. Cold Creek Valley Road has been determined as ineligible for listing on the National Register of Historic Places.

\subsection{Pit \#6}

Aerial photographs show extensive ground disturbance related to active use of the borrow area within the APE for Pit \#6. All of Pit \#6 was been investigated by a 1995 survey effort as part of the Horn Rapids Landfill capping project. No cultural resources have been recorded within the project APE. Several cultural resources investigations have been performed within the vicinity of Pit \#6, just west of the 300 Area since the late 1980s; the last survey was conducted in 2007. In addition, a number of cultural resources dating to the historic period have been identified by these surveys near the APE. A 1995 survey identified three historic sites located near the project area. These include one historic trash scatter consisting of glass fragments, metal cans, and other domestic refuse. The other two sites consist of possible building depressions or foundations. One of these sites consists of three depressions and seems to be associated with a historic agricultural area on its north side. All of these sites are currently unevaluated for listing on the National Register of Historic Places. As discussed in Section 4.4 (the cultural setting portion of this report), this site, especially near the current location of the 300 Area, played an important role in the early farming landscape on the Hanford Site. 


\subsection{Cultural Resources Field Inventory Methods}

As described in Section 5, most of the project APE has been inventoried for cultural resources with the exception of the Army Loop Road project area. Some of the APE has also witnessed extensive disturbance (i.e., Pit \#6, NRDWL/SWL). However, the surveys completed at the NRDWL/SWL project area are outdated. Therefore, the field inventory for this undertaking focused on an intensive pedestrian survey with 65-foot (20-meter) transects of undisturbed areas, re-surveying the NRDWL/SWL project area and surveying previously unsurveyed areas along Army Loop Road. Subsurface investigations were not conducted of the project APE because the literature review and the geologic setting of the project area indicate that the potential for buried cultural resources is low in the APE.

Pit \#6 is an existing borrow pit that is previously disturbed. Area $\mathrm{C}$ has no potential to contain buried cultural resources, as indicated by previous geological and cultural studies of the area. According to the cultural model developed for the Hanford area, no temporary or permanent settlements would have occurred in this area during prehistoric times unless there was a time in the past when water flowed through Cold Creek regularly. There is no evidence that water ever flowed through Cold Creek in this fashion, and this area has been determined to contain a low potential for subsurface cultural deposits. According to geological studies of the area, this zone has large sand deposits that lie on top of the older Pleistocene slackwater flood deposits. Due to the fact that these have been interpreted as ephemeral stream deposits and only a small number of isolated artifacts have been identified within the area, it is unlikely that subsurface cultural deposits exist in the area. The geomorphology suggests that there is some potential for buried cultural resources along Army Loop Road and at the NRDWL/SWL. Minimal ground disturbance will take place in those areas targeted for expansion along Army Loop Road, mostly in the form of blading. In addition, pockets of moderate ground disturbance will take place in the support zone. Although some potential for buried cultural deposits exist, these are minimal. Additionally, it should be noted that the literature review suggests that the potential for pre-contact archaeological sites is low, with a moderate potential for historic sites associated with post-1943 Manhattan Project/Cold War activities, which are more likely to be manifested as surface deposits. 


\subsection{Cultural Resources Field Inventory Results}

Fieldwork for the cultural resource inventory was completed on March 16 and 17, 2010, by Keith Mendez of CH2M HILL with the assistance of Jim Christensen of HKA Enterprises (HKA), and on March 23 and 24, 2010, by Jim Christensen and Kathleen Lowe of HKA and Jennifer Gutzeit of PNNL. All fieldwork was executed under the direction of Jim Sharpe of the CH2M HILL office in Richland, Washington. In total, 424 acres were inventoried for this undertaking. The weather was mild and sunny with temperatures varying between $50^{\circ} \mathrm{F}$ and $60^{\circ} \mathrm{F}$.

A northern and southern corridor of Army Loop Road beginning at the intersection of Beloit Avenue ending at the intersection at Route 4 South on the eastern end and a 1,640-foot (500-meter) buffer surrounding the NRDWL/SWL were inventoried by archaeologists walking in parallel 65 -foot (20-meter) transects in an effort to identify, document, and evaluate cultural resources that might be affected by the proposed undertaking. Additionally, two transects were walked along the east and west sides of Beloit Avenue from State Route 240 to Army Loop Road. Survey strategies along Beloit Avenue and Army Loop Road were similar, in that individual archaeologists surveyed each side of the road covering a 65-foot (20-meter) corridor along the north and south side of the road (see Figures 7.1 and 7.2). For the 1,640-foot (500-meter) buffer around the NRDWL/SWL, archaeologists began at the northeastern corner spaced at 65-foot (20-meter) intervals and advanced in a westerly direction, meandering transects east and west. Once on the northern boundary of the survey area, the survey crew then continued this process in the opposite direction, along the eastern edge of the NRDWL/SWL area, with transects meandering in a north and south direction. This process was repeated for the southern boundary and the western boundary as well (Figure 7.2).

Features associated with the National Register-eligible AAA archeological sites 45BN1029 and 45BN01606 were identified in the project APE during the cultural resources inventory. Updated site forms were completed, and site boundaries were modified. Observations made during the site revisit at 45BN1029 noted that wooden structural elements have been completely destroyed by fire, and exposed sandbags employed in the construction of these features were burned away. The earthen berm and sandbag elements of these revetments, however, retain a high degree of integrity and still convey feeling of historical association consistent with a domestic anti-aircraft artillery site of the 1950s. Artifacts associated with dump features were recorded in more detail, confirming a 1951-1955 occupation of this site. Site recording at 45BN01606 identified several additional features that were documented in detail and added to the updated site form. Both sites are considered to still be eligible for inclusion in the National Register as contributing properties to the Manhattan Project/Cold War Era Historic District for their potential to provide important information about the configuration and functions of the structures constructed at AAA sites.

Army Loop Road is a historical linear cultural resource site that had not been documented prior to this inventory. Army Loop Road, also called the Valley Road, is one of the primary service roads that formerly served the 600 Area of the Hanford Engineer Works (HEW) and, later, the Hanford Site. This is an example of one of the secondary roadways established by DuPont's Wilmington Division in 1943, forming "a complete transportation network" from which the HEW could be developed across the remote landscape (Marceau et al. 2003, p. 2-1.6). The designation "Army Loop Road" was applied when the 6th Army, 5th Artillery Group (Air Defense) developed a network of nine anti-aircraft artillery positions in the 600 Area, mostly along this road. Army Loop Road was, at this time, upgraded and paved in an effort 
to support the construction and service of $90-\mathrm{mm}$ and $120-\mathrm{mm}$ antiaircraft artillery brigade facilities. The updated road reflects its current condition as a culvertized engineered and compacted-earth, bituminous macadam road with elements of cut-and-fill design consistent with U.S. Army Corps of Engineers (USACE) material and workmanship specific to the post-World War II Cold War era of the 1950s.

The AAA batteries remained in use until the 1955 implementation of Nike surface-to-air missile defense systems outmoded $90-\mathrm{mm}$ and 120-mm AAA defenses, leading to the rapid elimination of the Army's artillery air defense program. After this period, however, it appears that Army Loop Road continued to serve military interests for training in the 600 Area.

Army Loop Road, in its current condition, like nearly all roads constructed by the USACE, is asphalt with a 2-inch-thick (5-cm-thick) bituminous mat surface over either a 3- or 5-inch ( 7 - or 12-centimeter) base of crushed rock or stabilized aggregate. The road is 16 feet ( 5 meters) wide and approximately 9 miles (14 kilometers) long. It possesses galvanized corrugated metal pipe culverts and does not appear to have been resurfaced or otherwise maintained during the Cold War period. It has undergone standard maintenance throughout the years, including resurfacing, widening, and striping; the major modifications to historical materials and workmanship are evident only along the eastern 1 mile (2 kilometers) of the documented segment.

CH2M HILL has determined that Army Loop Road is not eligible for listing on the National Register of Historic Places. Army Loop Road is part of a larger network of roads that run throughout the Hanford Site and is located in the central area of Camp Hanford. The period of significance for the Hanford Site is from 1943 through 1961, when Camp Hanford closed (DOE-RL 1998). All buildings that served the mission of the Hanford Site along Army Loop Road have been demolished; without these structures, the road lacks the context of its original purpose. As one part of the road network as a whole, it may be considered a contributing feature to the Manhattan Project/Cold War Era Historic District, but Army Loop Road is not associated with events that have made significant contributions to the broad patterns of local, regional, or natural history and thus is not eligible under Criterion A or B. Additionally, $\mathrm{CH} 2 \mathrm{M}$ HILL has determined that the site is not architecturally significant. As one of many functioning roads in the area, Army Loop Road does not represent a design or engineering achievement and is not eligible under Criterion C. Last, CH2M HILL has determined that minor alterations have been undertaken on portions of the road, including resurfacing, widening, and striping various sections, negatively impacting its integrity of workmanship. Although the road maintains integrity of design, materials, and location, all structures that were located along it have been demolished; thus it does not retain integrity of feeling or association from its period of significance. Additionally, because it is a paved road, it is unlikely to yield important information in prehistory or history and is not eligible for the National Register of Historic Places under Criterion D.

It should be noted that during field survey of the area, archaeologists also observed military refuse as well as refuse from consumables available from the civilian market dating to the 1950s. Based on date and type, these artifacts are likely associated with use of Army Loop Road. These items were observed but not formally recorded. Two historic cans were observed within the NRDWL/SWL survey area (outside the fence line) but not formally recorded. No other cultural resources were identified by the cultural resources inventory. 

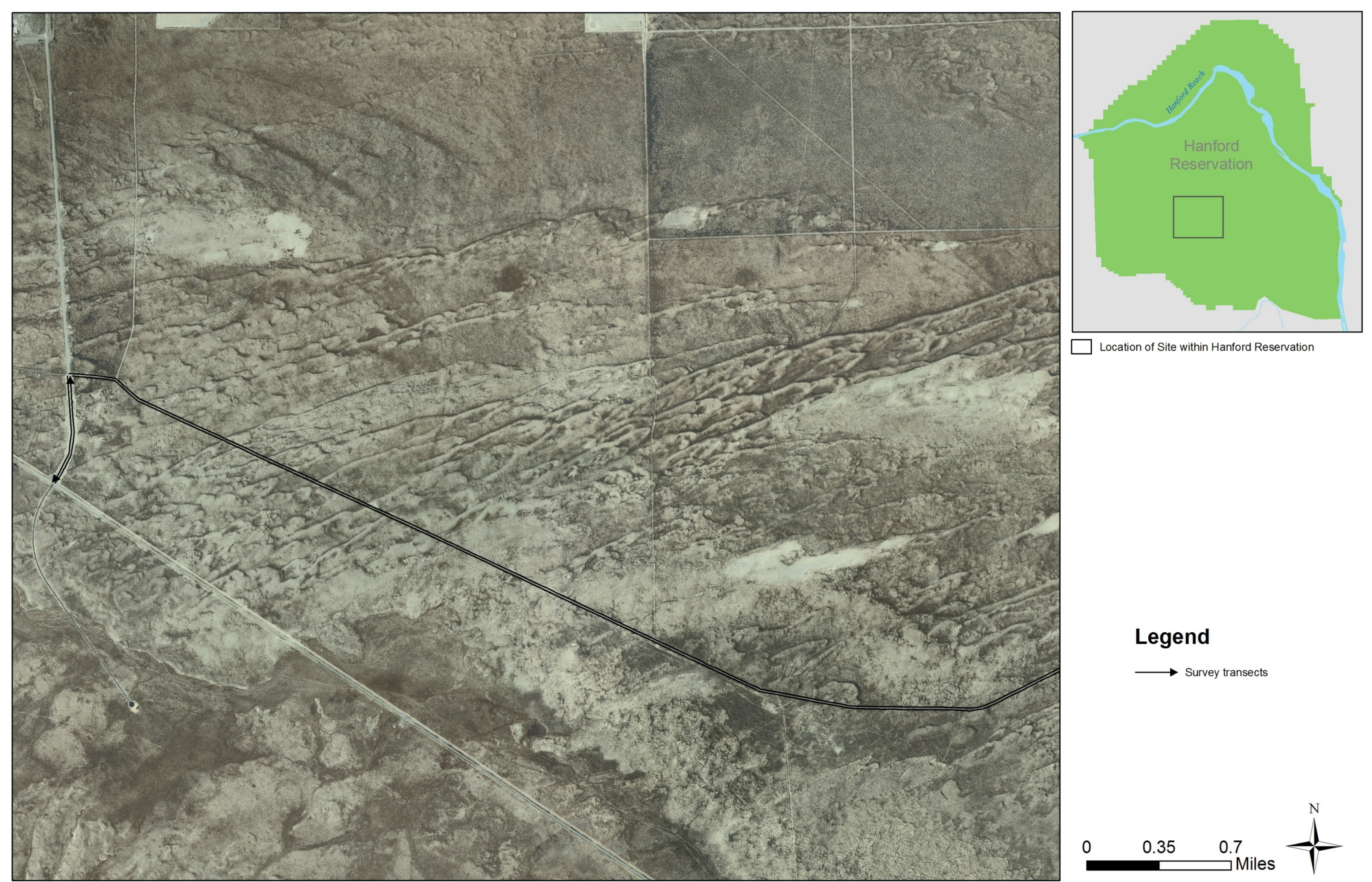

$\square$ Location of Site within Hanford Reservation

Figure 7.1. Survey transects (65 feet; 20 meters) for the field inventory of Beloit Avenue and the western portion of Army Loop Road overlaid on a 2006 aerial photograph. 

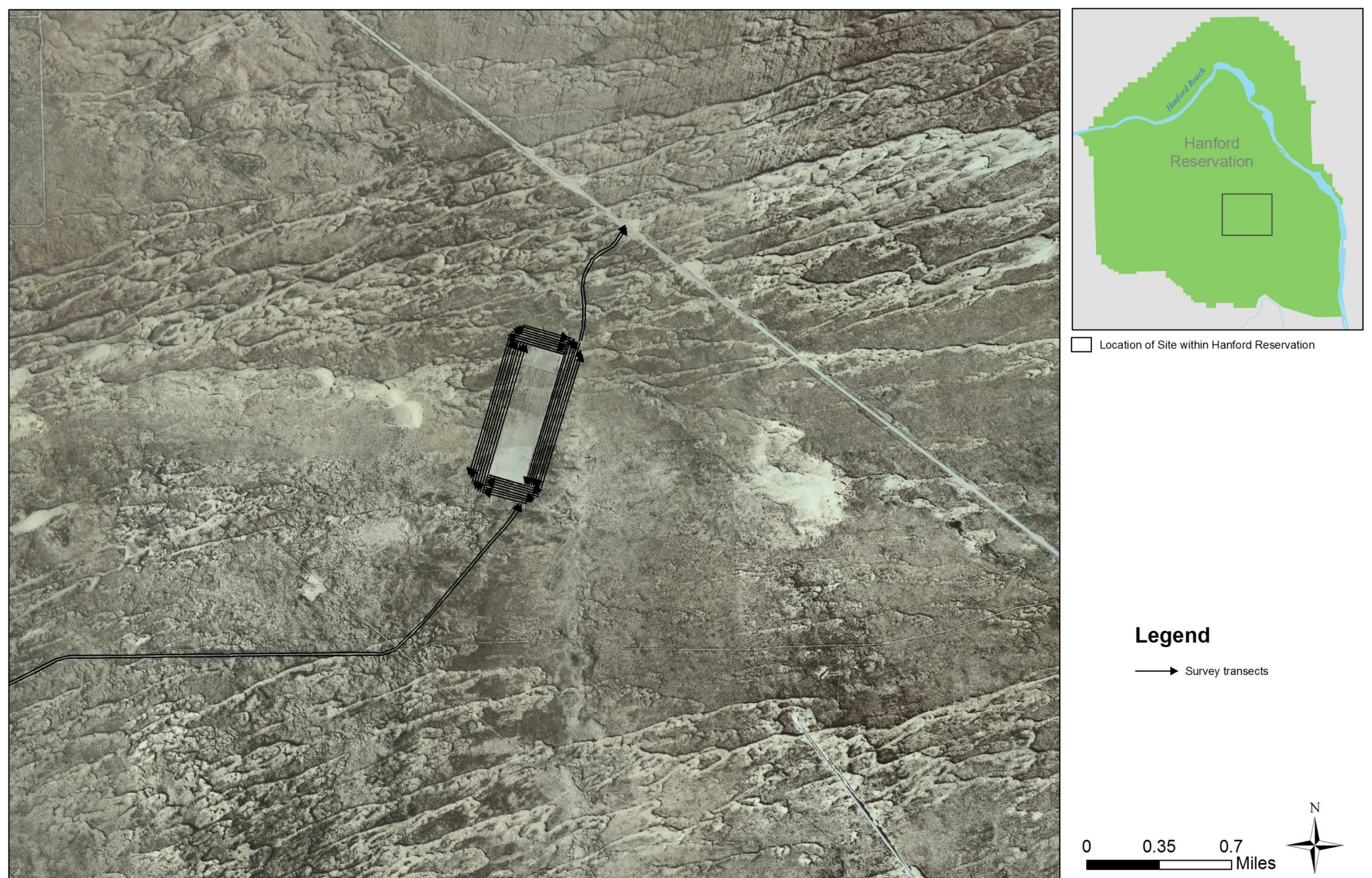

$\square$ Location of Site within Hanford Reservation

\section{Legend}

$\longrightarrow$ Survey transects

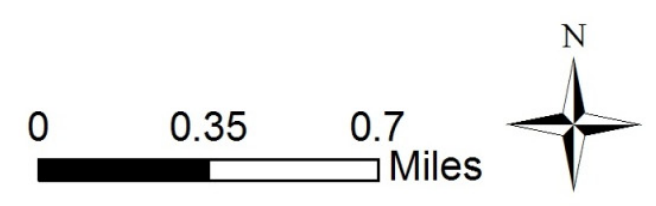

Figure 7.2. Survey transects ( 65 feet; 20 meters) for the field inventory of the eastern portion of Army Loop Road to Route 4 South and the NRDWL/SWL area overlaid on a 2006 aerial photograph. 


\subsection{Findings}

Several significant cultural resources are located within the project APE that will be impacted by this undertaking. They include Laliik, a National Register-eligible TCP, which overlaps with the area targeted for borrow silt material located at Area $\mathrm{C}$ and National Register-eligible historic archaeological sites 45BN1029 and 45BN01606. Adverse effects to Laliik cannot be avoided by this undertaking and are being addressed in the draft "Amended Memorandum of Agreement (MOA) For Use of the Borrow Source at Area C, Hanford Site, Richland, Washington." The MOA was signed by DOE-RL, the Washington SHPO, and Advisory Council on Historic Preservation (ACHP) in early 2009. Currently, the 2009 MOA is being amended to include landfills and additional soils needed from Borrow Area C. The amended MOA is included in the Appendix.

Based on the findings from the cultural resources inventory and this assessment, the project intends to expand Army Loop Road to the north where the two National Register-eligible archaeological sites, 45BN1029 and 45BN01606, are located, to avoid impacting these resources. The rest of the road will be preferentially expanded on the southern side to minimize impacting locations along the northern side of the road where habitat is more highly developed. Because impacts to these sites will be avoided, this undertaking will result in no adverse effect to these historic properties. In addition, because Army Loop Road is ineligible for listing on the National Register of Historic Places, there will be no effect to historic properties from the expansion and modification of the roadway. 


\subsection{Administrative Process for Compliance with 36 CFR 800}

This assessment will be transmitted to DOE-RL, the federal agency responsible for making an official determination on the finding of effect for this undertaking. DOE-RL will submit its finding to the tribes and the Washington SHPO for its review as part of the consultation process outlined in 36 CFR 800. The SHPO and the tribes have 30 days from receipt of this document to provide an opinion. Following receipt of their comments, if any, the project will be notified of any additional conditions required in order for this activity to begin. Project activities cannot be initiated until the project has received notification that the review period has ended and the project may proceed.

Although no cultural resources are anticipated, all workers must be directed to watch for cultural materials (e.g., bones, stone tools, mussel shell, bottles, bricks, nails, cans, military items) during all work

activities. If any cultural materials are encountered, work in the vicinity of the discovery must stop until a cultural resources specialist has been notified, the significance of the find assessed, appropriate tribes notified, and, if necessary, arrangements made for mitigation of the find. In the event of any discoveries, please contact PNNL Cultural Resources Project staff.

The DOE-RL Tribal Affairs and Cultural Resources Program maintains copies of this assessment and associated records in its archive room at PNNL, located at the Sigma V Building, 3110 Port of Benton Boulevard, Richland, Washington. 


\subsection{References}

Bard JC. 1997. "Ethnographic /Contact Period (Lewis and Clark 1805 - Hanford Engineer Works 1943) of the Hanford Site, Washington." In National Register of Historic Places Multiple Property Documentation Form - Historic, Archaeological and Traditional Cultural Properties of the Hanford Site, Washington. DOE/RL-97-02, U.S. Department of Energy Richland Operations Office, Richland, Washington.

Barton BR. 1999. "Some Notable Finds of Columbian Mammoths from Washington State." Washington Geology 27(2/3/4):23-27.

Bjornstad BN. 2006. On the Trail of the Ice Age Floods. Keokee Co. Publishing, Inc., Sandpoint, Idaho.

Chatters JC. 1982. "Prehistoric Settlement and Land Use in the Dry Columbia Basin." Northwest Anthropological Research Notes 16:125-147.

Daugherty RD. 1952. “Archaeological Investigations of O’Sullivan Reservoir, Grant County, Washington." American Antiquity 17:274-278.

DOE. 1988. Consultation Draft, Site Characterization Plan, Reference Repository Location, Hanford Site, Washington. DOE/RW-0164, Vol. 1 and 2, U.S. Department of Energy, Washington, D.C.

DOE-RL. 1997. National Register of Historic Places Multiple Property Documentation Form - Historic, Archaeological and Traditional Cultural Properties of the Hanford Site, Washington. DOE/RL-97-02, U.S. Department of Energy Richland Operations Office, Richland, Washington.

DOE-RL. 1998. Hanford Site Manhattan Project and Cold War Ear Historic District Treatment Plan. DOE/RL-97-56, Rev. 1, U.S. Department of Energy Richland Operations Office, Richland, Washington.

DOE-RL. 2002. Standardized Stratigraphic Nomenclature for Post-Ringold Formation Sediments Within the Central Pasco Basin. DOE/RL-2002-39, Rev. 0, U.S. Department of Energy Richland Operations Office, Richland, Washington.

DOE-RL. 2003. Hanford Cultural Resources Management Plan. DOE/RL-98-10, Rev. 0, U.S. Department of Energy, Richland Operations Office, Richland, Washington.

DOI. 1994. Hanford Reach of the Columbia River: Comprehensive River Conservation Study and Environmental Impact Statement - Final, Volumes I and II. U.S. Department of the Interior, Washington, D.C.

Duncan JP, KW Burk, MA Chamness, RA Fowler, BG Fritz, PL Hendrickson, EP Kennedy, GV Last, TM Poston, MR Sackschewsky, MJ Scott, SF Snyder, MD Sweeney, and PD Thorne. 2007. Hanford Site National Environmental Policy Act (NEPA) Characterization. PNNL-6415, Rev. 18, Pacific Northwest National Laboratory, Richland, Washington.

Greene GS. 1975. Prehistoric Utilization of the Channeled Scablands of Eastern Washington. Ph.D. dissertation, Department of Anthropology, Washington State University, Pullman. 
Greengo RE. 1982. Studies in Prehistory: Priest Rapids and Wanapum Reservoir Areas, Columbia River, Washington. Department of Anthropology, University of Washington, Seattle.

Last GV and K Winsor. 2007. "Impacts of Ice Age Floods on Pleistocene Mammoths of Southeastern Washington." Geological Society of America, Abstracts with Program. Cordilleran Section - 103rd Annual Meeting (4-6 May 2007), Bellingham, Washington.

Leonhardy FC and DG Rice. 1970. "A Proposed Cultural Typology for the Lower Snake River Region, Southeastern Washington.” Northwest Anthropological Research Notes 4(1):1-29.

Marceau TE, DW Harvey, and DC Stapp. 2003. Hanford Site Historic District: History of the Plutonium Production Facilities, 1943-1990. Battelle Press, Columbus, Ohio.

Myers CW and SM Price (eds). 1979. Geologic Studies of the Columbia Plateau, A Status Report. RHO-BWI-ST-4, Rockwell Hanford Operations, Richland, Washington.

Newcomb RC, JR Strand, and FJ Frank. 1972. Geology and Ground-Water Characteristics of the Hanford Reservation of the U.S. Atomic Energy Commission, Washington. Professional Paper 717, U.S. Geological Survey, Reston, Virginia.

O'Conner JE and JE Costa. 2004. The World's Largest Floods, Past and Present - Their Causes and Magnitudes. Circular 1254, U.S. Geological Survey, Reston, Virginia.

Quigley TM, RW Haynes, and RT Grasham (eds). 1996. Integrated Scientific Assessment for Ecosystem Management in the Interior Columbia Basin. General Technical Report PNW-GTR-382, Pacific Northwest Research Station, U.S. Department of Agriculture Forest Service, Portland, Oregon.

Relander C. 1956. Drummers and Dreamers. Caxton Printers, Caldwell, Idaho.

Spier L. 1936. Tribal Distribution in Washington. General Series in Anthropology No 3, George Banta Publishing Co., Menasha, Wisconsin.

Waitt RB. 1994. "Scores of Gigantic, Successively Smaller Lake Missoula Floods Through Channeled Scabland and Columbia Valley." In Geologic Field Trips in the Pacific Northwest, DA Swanson and RA Haugerud (eds), pp. 1K-1-1K-88. Geological Society of America, Boulder, Colorado.

Walker DE Jr. 1998. Handbook of North American Indians. Volume 12: Plateau. Smithsonian Institution, Washington, D.C. 


\section{Appendix}

Amended Memorandum of Agreement 


\title{
Appendix
}

\section{Amended Memorandum of Agreement}

Enclosure 1

\author{
AMENDED MEMORANDUM OF \\ AGREEMENT \\ FOR USE OF THE BORROW SOURCE \\ AT AREA C, HANFORD SITE \\ RICHLAND, WASHINGTON
}




\section{AMENDED MEMORANDUM OF AGREEMENT FOR USE OF THE BORROW SOURCE AT AREA C, HANFORD SITE, RICHLAND, WASHINGTON BETWEEN THE U. S. DEPARTMENT OF ENERGY, THE WASHINGTON STATE HISTORIC PRESERVATION OFFICE, AND THE ADVISORY COUNCIL ON HISTORIC PRESERVATION WITH THE PARTICIPATION OF CONSULTING PARTIES: CONFEDERTATED TRIBES AND BANDS OF THE YAKAMA NATION, CONFEDERATED TRIBES OF THE UMATILLA INDIAN RESERVATION, THE NEZ PERCE TRIBE, AND THE WANAPUM}

WHEREAS, the U.S. Department of Energy (DOE), will be constructing a soil surface barrier over waste sites and/or landfills located on the Hanford Site. This initial barrier will be located on the Hanford Site and will entail use of approximately 450,000 cubic yards of finegrained soils from borrow source Area C. Borrow source Area C is located in the 600 Area. Construction of a surface barrier will cover a waste site and/or landfill located on the Hanford Site (Figure 1). Excavation will directly disturb approximately 40 -acres up to a depth of approximately 15 feet. Approximately 5 additional acres may also be used for work staging areas and to maintain safe access around the excavation area. The surface barrier will be monitored for effectiveness over a period of at least 5 years; and

WHEREAS, DOE conducted a cultural resources review of a larger 145-acre area for Area $\mathrm{C}$ borrow source development in June 2006 under HCRC\#2006-600-008. This action will focus on the approximately 45 acre development located within the original 145 -acre cultural resource review area; and

WHEREAS, DOE has determined that excavation activities at the borrow Area $\mathrm{C}$ source will result in an adverse effect to National Register-eligible historic property (i.e., portions of a Native American traditional cultural property known as Laliik). Potential Adverse effects include viewshed, noise, and air quality impacts as well as loss of native vegetation and habitat; and

WHEREAS, area Tribes (Confederated Tribes and Bands of the Yakama Nation, Confederated Tribes of the Umatilla Indian Reservation, the Nez Perce Tribe, and the Wanapum, herein referred to as Tribes) attach religious and cultural significance to Rattlesnake and Gable Mountains, and tribal access is protected under the American Indian Religious Freedom Act (1979) and Executive Order 13007; and

WHEREAS, DOE has consulted with the Washington State Historic Preservation Officer (SHPO), Advisory Council on Historic Preservation (ACHP), in accordance with Section 106 of the National Historic Preservation Act, 36 CFR Part 800.6(a) to resolve adverse effects on historic properties; and

WHEREAS, DOE seeks to avoid, minimize, or mitigate adverse effects to the National Register-eligible property. 
NOW, THEREFORE, the signatories agree that DOE, will ensure the following stipulations are implemented in order to take into account the effects of the undertaking on historic properties, and that these stipulations shall govern the undertakings and all of its parts until this MOA expires or is terminated.

\section{STIPULATIONS}

DOE will ensure that the following stipulations are carried out:

\section{A. MINIMIZATION, MITIGATION, MONITORING AND REPORTING}

\section{MITIGATE ADVERSE EFFECTS TO CULTURAL INTEGRITY OF HABITAT AND TO TRADITIONAL PLANTS}

1. In consultation with the SHPO, ACHP, and Tribes, DOE will complete and distribute a culturally relevant native plant revegetation strategy for this 45 acre project within 12 months of signing this MOA.

2. In consultation with the SHPO, ACHP, and Tribes, DOE will update the habitat quality determination for the 45 acre portion of Area $\mathrm{C}$ borrow source, specifically focusing on the stabilized dune areas, within 6 months of signing this MOA.

3. In consultation with the SHPO, ACHP, and Tribes, DOE will implement a 5-year annual monitoring plan to confirm success of reclamation and health of wildlife habitat at the 45acre area disturbed by project activities.

4. DOE will invite Tribes to participate in ecological surveys and revegetation efforts at Area C. DOE will notify the tribes at least one month prior to the anticipated initiation of surveys and re-vegetation efforts.

\section{MINIMIZATION AND AVOIDANCE OF VISUAL, AIR QUALITY AND NOISE IMPACTS}

5. To minimize visual and noise effects of project activities, DOE will coordinate timing of construction to assure that these activities do not unnecessarily interfere with Tribal ceremonial activities and religious use of Rattlesnake Mountain (Laliik). To assist DOE with implementing this stipulation, the tribes will notify the DOE Indian Nation Program at least one month prior to the anticipated ceremonial activities and religious uses of Rattlesnake Mountain (Laliik).

6. To minimize visual and air quality impacts resulting from the excavation, DOE will implement interim soil stabilization controls through the implementation of dust control procedures such as the application of a tackifier and routine watering of the area.

7. To minimize long-term visual and air quality impacts resulting from the excavation, DOE will develop a long-term reclamation plan within 12 months of signing this MOA.

8. To minimize long-term visual and air quality impacts resulting from the excavation, DOE will monitor the viewshed from a culturally relevant perspective on a seasonal basis. 


\section{CULTURAL RESOURCES MONITORING}

9. DOE will conduct routine periodic cultural resources monitoring, with tribal participation, during excavation activities. Additional details are included in the Implementation Plan.

10. DOE will assure that all project activities adhere to Inadvertent Discovery of Human Remains Protocols and Unanticipated Discovery Protocols outlined in the U.S. Department of Energy, Richland Operations Office, Hanford Cultural Resources Management Plan (DOE 2003) and in compliance with the Native American Graves Protection and Repatriation Act (NAGPRA) 1990 and 36 CFR 800.13.

\section{REPORTING}

11. DOE will provide quarterly electronic reporting to all parties on the implementation of the stipulations 1-10 in this MOA over the duration of the project. Initiation of these quarterly updates will occur 3 months after earth-moving activities have started at Borrow Area C

12. DOE will provide annual reporting to all parties on the implementation and results of the monitoring plan of the success of revegetation and soil reclamation/ stabilization efforts over the course of the five-year monitoring effort (as per the Revegetation Plan and Reclamation Plan, identified in stipulations 1 and 7).

\section{ADMINISTRATIVE PROVISIONS}

\section{Dispute Resolution}

The Parties will work together to collaborate and resolve any differences or disputes informally. If necessary, the Parties will elevate significant disputes to the appropriate management levels of the organizations for resolution. At this point the following steps will be followed:

1. Should the SHPO or ACHP raise an objection to an action taken under the MOA, or have a dispute regarding fulfillment of the terms of this MOA, that party will file a written notice with RL.

2. Upon receipt of a written notice from the SHPO or ACHP, RL will consult with the party filing the notice to resolve the dispute. RL will also notify the Tribes of the objection or dispute.

3. If RL cannot resolve the objection or dispute within 60 calendar-days of receipt of the written notice, DOE will forward to the ACHP documentation of the dispute, a written proposal for its resolution, and request the ACHP's comment.

4. Within 30 calendar-days of receipt of the written submittal, the ACHP shall either:

a. Notify RL that it will not consider the dispute or provide recommendations, in which case the Agency may proceed with the proposed action; or, 
b. Concur with RL's proposed response to the dispute, whereupon DOE may proceed in accordance with the agreed-upon response; or,

c. Provide RL with recommendations, which RL will consider in good faith in reaching a final decision regarding a response to the dispute.

5. RL shall take into account any SHPO or ACHP recommendation or comment provided in accordance with this stipulation with reference only to the subject of the objection or dispute; RL's responsibility to carry out all actions under this MOA that are not the subject(s) of the objection or dispute shall remain unchanged. While the dispute is being resolved, the MOA continues in effect without change or suspension.

6. If the ACHP or SHPO is contacted by a concurring party Tribe or by a member of the public to discuss a significant concern or objection about implementation of the terms of this MOA, the contacted entity will notify RL of the issue.

7. RL will keep consulting parties and Tribes apprised of any concerns or objections raised and how the concern is resolved.

Amendments The signatories may propose, in writing, and will consider amendments to this MOA. Notice of any proposed amendments will also be provided to the other parties to this MOA.

\section{$\underline{\text { Effective Date and Termination }}$}

This amended MOA will become effective on the date that it has been signed by all signatory parties and then supersedes all provisions of the existing MOA (which was effective April 4, 2009). DOE has committed significant resources to meet the terms of this agreement prior to its effective date, and will continue to commit significant resources to planning and implementing the reclamation. Any signatory party who wishes to terminate the MOA must do so in accordance with the regulations at 36 CFR 800.6(c)(8).

\section{$\underline{\text { Coordination }}$}

RL will ensure that each consulting party is provided a copy of the fully executed MOA as amended. 
Signatory Parties:

\section{U.S. Department of Energy}

By:

Date:

David A. Brockman

Manager

Washington State Historic Preservation Office

By:

Dr. Allyson Brooks

Date:

Washington State Historic Preservation Officer

Advisory Council on Historic Preservation

By: Date:

John M. Fowler

Executive Director

Concurring Parties:

Confederated Tribes of the Umatilla Indian Reservation

By: Date:

\section{Confederated Tribes and Bands of the Yakama Nation}

By: Date:

Nez Perce Tribe

By: Date:

\section{Wanapum}

By: Date: 


\section{Distribution}

No. of

Copies

ONSITE

4 DOE Richland Operations Office

JA Conrad

KD Leary

AL Rodriguez

MK Wright
No. of

Copies

CH2M HILL Plateau Remediation

Company

MT Jansky

H8-45

A7-75

A6-38

A $7-75$

A7-75
2 Pacific Northwest National Laboratory

JL Gutzeit

K6-75

EP Kennedy 


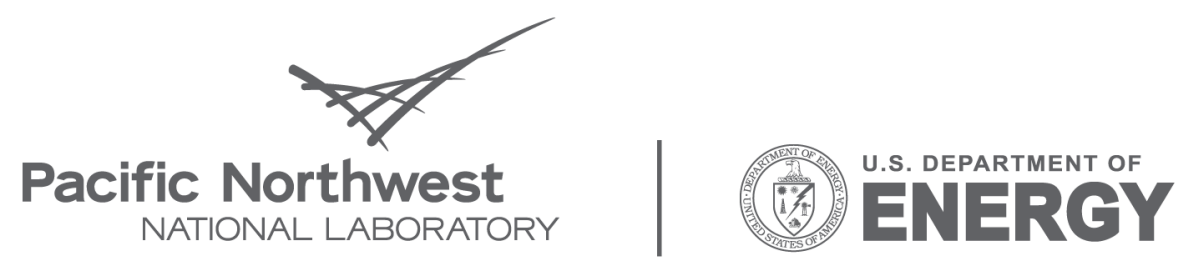

Proudly Operated by Battelle Since 1965

902 Battelle Boulevard

P.O. Box 999

Richland, WA 99352

1-888-375-PNNL (7665)

www.pnl.gov 